\title{
Microbially-mediated carbonate dissolution and precipitation; towards a protocol for ex-situ, cave-analogue cultivation experiments
}

\author{
Vanessa E. Johnston (1D 1,2*, Andrea Martín-Pérez (D) ${ }^{1}$, Sara Skok (D) ${ }^{2}$ and Janez Mulec (D) ${ }^{2,3}$ \\ ${ }^{1}$ Research Centre of the Slovenian Academy of Sciences and Arts, Ivan Rakovec Institute of Palaeontology, Novi trg 2, 1000 Ljubljana, Slovenia \\ ${ }^{2}$ Research Centre of the Slovenian Academy of Sciences and Arts, Karst Research Institute, Titov trg 2, 6230 Postojna, Slovenia \\ ${ }^{3}$ University of Nova Gorica, UNESCO Chair on Karst Education, Glavni trg 8, 5271 Vipava, Slovenia
}

\begin{abstract}
Subterranean calcite dissolution and precipitation are often considered as strictly geochemical processes. The active involvement of microbes in these processes is commonly underestimated in the literature due to general oligotrophic conditions in caves, except in particular cave conditions, such as sulfidic caves and moonmilk deposits, where the presence of microbes likely plays a key role in mineral deposition. Here, we study the possible involvement of microbes from Postojna Cave, Slovenia, in carbonate dissolution (litholysis) and precipitation (lithogenesis). Microbes were sampled from small pools below hydrologically diverse drip sites and incubated on polished limestone tablets at 10 and $20^{\circ} \mathrm{C}$ for 2 and 14 weeks under cave-analogue conditions. The tablets were then observed under scanning electron microscope to investigate microbe-rock interactions. Our experiments showed the presence of various microbial morphotypes, often associated with extracellular polymeric substances, firmly attached on the surfaces. Unfortunately, our surface sterilization method using $96 \%$ and $70 \%$ ethanol could not establish the complete aseptic conditions in deep natural cracks in the experimental limestone tablets. Nonetheless, our results emulate the interaction of environmental microbes with limestone rock. Conspicuous calcite dissolution and precipitation were observed in association with these microbes. Furthermore, we show evidence of entombment of microbes in a Si-rich precipitate during nutrient-depleted growth conditions and we suggest that microbial involvement in silica mobilization under ambient conditions may be a widespread and often overlooked phenomenon. Our findings have important implications for microbial-mediation of cave carbonate dissolution and precipitation, including the preservation of past climate proxy signals in speleothems and prehistoric cave art. Improvements to the methodology and further work are suggested to enable more robust ex-situ cultivation experiments in the future, facilitating better and more detailed research into this topic.
\end{abstract}

Keywords: $\quad$ cave microbes, microbially-mediated calcite dissolution, microbially-mediated calcite precipitation, cultivation experiment, scanning electron microscopy

Received 22 December 2020; Revised 9 April 2021; Accepted 12 April 2021

Citation: Johnston, V.E., Martín-Pérez, A., Skok, S., Mulec, J., 2021. Microbially-mediated carbonate dissolution and precipitation; towards a protocol for ex-situ, cave-analogue cultivation experiments. International Journal of Speleology, 50(2), 137-155. https://doi.org/10.5038/1827-806X.50.2.2372

\section{INTRODUCTION}

Weathering and precipitation of carbonate sediments and rocks play major roles in the geochemical carbon cycle (Ridgwell \& Zeebe, 2005). It is well known that microbes can interact with calcite during carbonate weathering processes. However, it is highly debated whether microbes enhance or inhibit the weathering rate, as contradictory evidence exists for both processes (Davis et al., 2007; Jacobson \& Wu, 2009). It has been found that microbes can produce, for example, organic acids that locally modify the $\mathrm{pH}$, leading to calcite dissolution. Additionally, microbially-produced enzymes, such as carbonic anhydrase, can catalyze the interconversion of $\mathrm{CO}_{2}$ and water and the dissociated carbonic acid ions $\left(\mathrm{CO}_{2}+\mathrm{H}_{2} \mathrm{O} \leftrightarrow \mathrm{H}^{+}+\mathrm{HCO}_{3}{ }^{-}\right)$, releasing $\mathrm{H}^{+}$ions, promoting calcite dissolution (Li et al., 2006). Furthermore, physical weathering caused by borings of fungal hyphae can decrease the structural integrity of a rock and increase the superficial area available for chemical dissolution, while surface water retention via biofilms can lead to freeze-thaw destructive processes (Lian et al., 2008; Kip \& van Veen, 2015). By contrast, the presence of microbes on calcite surfaces has been 
found to block dissolution sites, causing a significant reduction in the dissolution rates (Lüttge \& Conrad, 2004; Davis et al., 2007). Furthermore, microbiallyinfluenced calcite precipitation (bio-calcite) has been well-documented and advocated as a remediation method for strengthening damaged concrete for use in construction and the conservation of historic buildings and monuments (De Muynck et al., 2010). Research suggests that microbes may initiate either calcite dissolution or precipitation depending on the environmental conditions and, in particular, when non-ionic organic matter and ammonium are available as a nutrient source (Jacobson \& Wu, 2009).

Microbial-mineral interactions have been recognized in cave environments (Barton \& Northup, 2007; Lavoie et al., 2010; Jones, 2010). However, research has focused on the involvement of different microorganisms in the precipitation of certain types of speleothems, such as moonmilk (Cañaveras et al., 2006; Curry et al., 2009; Braissant et al., 2012; Miller et al., 2018), pool fingers (Melim et al., 2001), and "mushroom speleothems" (Bontognali et al., 2016). Microbial dissolution seems to be involved in the formation of corrosion residues (Cunningham et al., 1995), biofilms and patinas (De Leo et al., 2012), while certain sulfide-oxidizing bacteria can considerably contribute to carbonate dissolution in sulfuric acid caves (Engel et al., 2004). In some cases, cave microbes can cause both dissolution and precipitation of $\mathrm{CaCO}_{3}$, as is the case of Actinobacteria, where the predominance of one or the other process depends on the surrounding environmental conditions (Cuezva et al., 2012) and the nutrient supply (Maciejewska et al., 2016). However, many of these studies have focused on highly specific cave features or particular geochemical conditions, while little work has investigated the precise microbecalcite interactions under dark, oligotrophic condition on simple limestone rock, similar to a typical karst cave host-rock.

Here, we inoculated carbonate tablets with microbes taken from a cave environment to investigate the interactions of these microbes with carbonate surfaces using Scanning Electron Microscope (SEM) imaging. In particular, we wanted to see if the microbes initiated calcite dissolution and/or precipitation in a simple oligotrophic setting under ambient, caveanalogue experimental conditions. Here, as an example, we focused on cup-shaped dissolutional pools situated below drip points that are found in abundance in a chamber of Postojna Cave, Slovenia. The formation of these pools is mainly attributed to geochemical dissolution in conjunction with high $\mathrm{CO}_{2}$ cave conditions (Johnston et al., 2018; Kukuljan et al., 2021). However, we hypothesize that microbes are also involved in the formation of these dissolutional features. Accordingly, our study focuses on the role of microbes in the processes of carbonate dissolution and precipitation on limestone rocks under caveanalogue conditions. Later, we outline a number of improvements to the methodology used here that we encourage be taken into consideration when planning similar ex-situ cave-analogue, cultivation experiments.

\section{METHODS}

\section{Cave setting and sampling protocol}

In order to identify possible calcite dissolution or precipitation mediated by microorganisms, drops of water containing microbes obtained from two cave sampling sites were used as inocula for carbonate tablets under controlled laboratory conditions and the resulting interactions between calcite and microbes were observed with an SEM. The samples originated from the terminal chamber (the Red Hall; Rdeča Dvorana "RD") of the Pisani rov passage of Postojna Cave (Postojnska jama), Slovenia $\left(45^{\circ} 46^{\prime} 52.5^{\prime \prime} \mathrm{N}\right.$, $14^{\circ} 12^{\prime} 20.5^{\prime \prime} \mathrm{E}$; Fig. 1). The overburden above the Red Hall is $34.5 \mathrm{~m}$ (Šebela, 2010). The surface above the cave is covered by karst soil, forest, and shrubs that provide an important organic input to the cave ecosystem via dripping water. In a previous study from other parts of Postojna Cave, it was estimated that a reasonable amount of microbial biomass constantly enters the karst aquifer via percolation water, reaching values of 5,100-19,990 cells per ml (Oarga-Mulec et al., 2017). In the Red Hall, there is a high density of cylindrical dissolution features on the cave floor, which often contain a small pool of water (Supplementary Fig. S1). Dissolution is thought to be mainly attributed to the water dripping into the cave and geochemical reactions with the seasonallyhigh $\mathrm{CO}_{2}$ concentrations (up to $10,000 \mathrm{ppm}$ in summer) in the cave air of this particular chamber (Krajnc et al., 2017; Kukuljan et al., 2021) causing the water to become corrosive (Johnston et al., 2018; Kukuljan et al., 2018). The drip sites provide water and accompanying organic compounds that have percolated from the karst soil (e.g., Hartland et al., 2011) and an environment that is always moist or with a water-filled pool. Furthermore, we have noticed that certain other sites in this chamber contain evidence for coexistent dissolution and precipitation (Johnston et al., 2019). This location, therefore, provides an optimum opportunity to investigate how cave microbes may interact with carbonate minerals, potentially enhancing or reducing the rate of limestone dissolution.

We selected two sampling sites in the Red Hall of Postojna Cave. RD1 is a relatively flat, dishshaped dissolutional feature with a diameter of $\sim 9 \mathrm{~cm}$ (Supplementary Fig. S2) that has formed below a cluster of multiple drips that respond quickly to rainfall events via fracture flow; at times, water rapidly pours down from the cave ceiling, while in other periods negligible dripping occurs. Therefore, the RD1 pool has a strongly variable rate of filling with water, and has a shallow pool during periods of high infiltration and is known to empty during particularly hot and dry summers. The RD5 dissolution feature has a cylindrical shape with a diameter of $\sim 6 \mathrm{~cm}$ and a slower, seasonal drip rate (Supplementary Fig. S3). Dripping continues even through very dry periods, albeit at an extremely slow rate (Table 1). The RD5 site tends to retain a small pool of water ( $2 \mathrm{~cm}$ deep). In the cave (date: 18 May 2018), the inner surface of dissolutional cup at each site (RD1 and RD5) was 


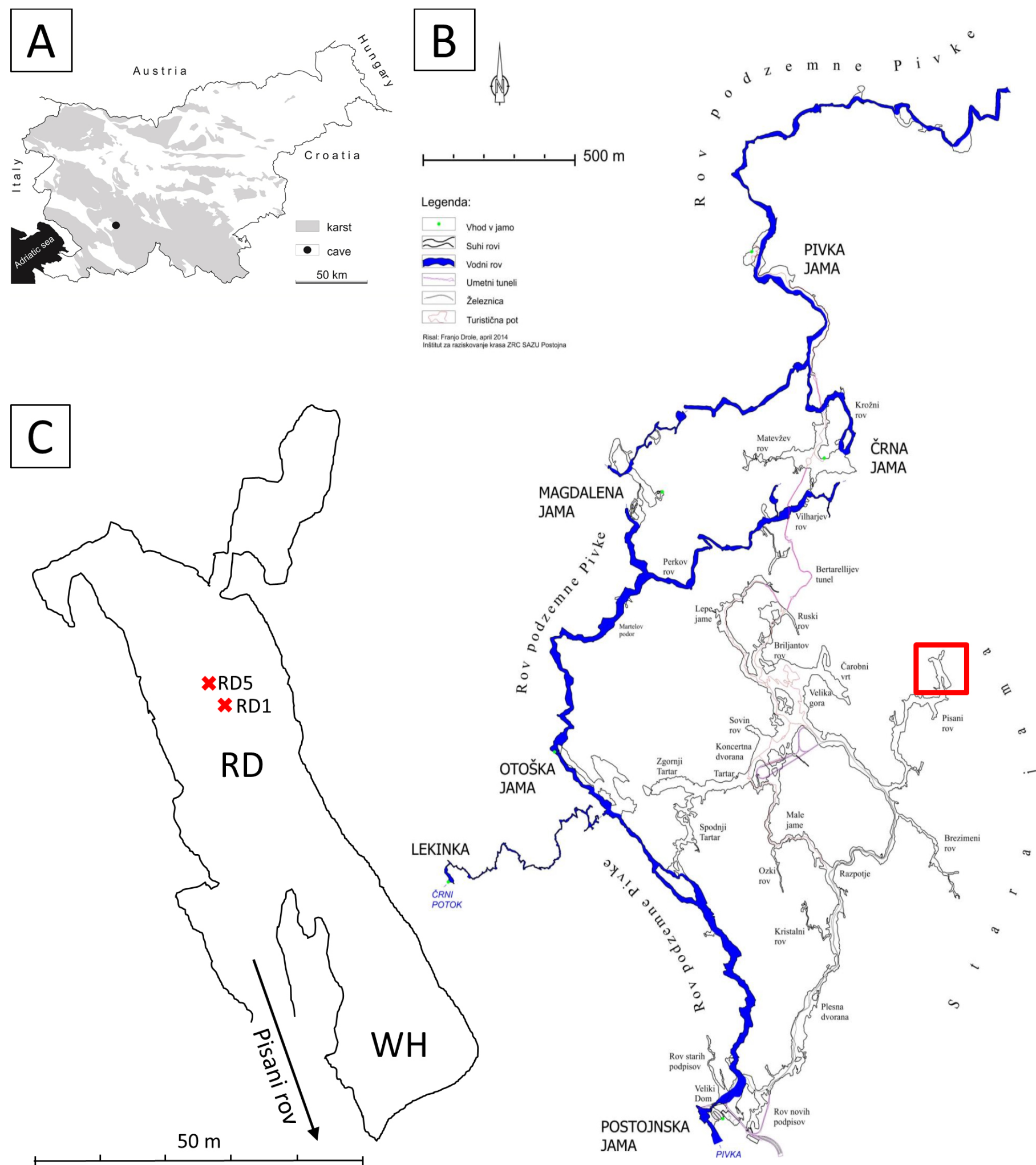

Fig. 1. Map of Postojna Cave and sampling locations. A) Map of Slovenia with cave site marked as black circle. B) Plan of Postojna Cave with the sampling location delimited by the red square. Note that the show cave entrance is at the bottom of the map and the blue shading shows the river passages. C) Detail of the area within the red square in B. The Red Hall (RD) and White Hall (WH) are shown along with the direction of the continuation of the Pisani rov passageway. The sampling sites (RD1 and RD5) are marked as red crosses. Map A was created using Surfer 14 (Golden Software, https://www.goldensoftware.com/). Map B was created by Franjo Drole (2014) and C was adapted from Luigi Gallino (1927), both found in the archive of the Karst Research Institute ZRC SAZU, Postojna.

swabbed with two FLOQSwabs ${ }^{\mathrm{TM}}$ (Copan), each swab covering opposite halves of the total surface area (nonquantified). The swabs were placed in sterile vials and immediately transported to the laboratory (Postojna).

\section{Cave water geochemistry}

After swabbing for microbe collection, the $\mathrm{pH}$ and temperature of the pool waters were measured in- situ using a portable WTW Multiline 3420 digital meter with an IDS SenTix ${ }^{\circledR} 940$ pH electrode. Not enough water was present in the pools to measure the conductivity with our equipment at the time of sampling. At the same time, approximately $50 \mathrm{ml}$ of water was collected from within each of the pools, RD1 and RD5, to use as a natural medium for eventual enhancement of microbial growth in one of the 
experimental setups. Water samples were collected and filtered on-site ( $0.45 \mu \mathrm{m}$ mesh) and analyzed for alkalinity by titration with $0.02 \mathrm{~N} \mathrm{HCl}$ (at the Karst Research Institute ZRC SAZU, Postojna, Slovenia) immediately on return from the cave, with alkalinity calculated using the Gran method. As part of a cave monitoring campaign including the sites studied here, cation and anion analyses were carried out by ion chromatography using a Shodex YK-421 (at the University of Nova Gorica, Slovenia) and cave air $\mathrm{CO}_{2}$ concentrations were measured using a handheld Vaisala GM70 meter with a GMP222 probe (measuring range 0-10,000 ppm). Saturation indices with respect to calcite $\left(\mathrm{SI}_{\mathrm{C}}\right)$ were calculated using PHREEQC; a computer program for geochemical calculations (Parkhurst \& Appelo, 2013).

\section{Experimental set-up}

Twenty-four tablets $(2.5 \times 1.5 \times 1 \mathrm{~cm})$ were made using the homogeneous, massive mudstone parts of commercial grade plates of Cretaceous limestone known under the commercial name "Dinarit" (Central Dalmatia, Croatia). This particular rock was chosen due to its homogeneity and isotropic petrographic properties on a centimeter scale (Supplementary Fig. S4), to avoid possible differential dissolution rates due to variable textures and chemical composition of the Postojna Cave host-rock (Supplementary Fig. S5). The upper surfaces of these tablets were flattened and lapped using a Logitech PM5 thin-section machine and successively polished using silicon carbide pads P1200 (15 $\mu \mathrm{m}$ grit size), P2500 (8 $\mu \mathrm{m})$, and P4000 (5 $\mu \mathrm{m})$ (Kemet, UK). The polishing aimed to create a flat, homogeneous, and comparable surface from which dissolution and/or precipitation of calcite that occurred during the experiment could be distinguished from the pre-experiment rock surface. Previous SEM trials showed that the polishing procedure used here created a sufficiently uniform surface that, even at high-resolutions, the rock appeared flat and only fine, straight polishing scratches remained. These polishing scratches were easily recognizable, and thus, clearly distinguishable from processes that may have occurred during the experiment (e.g., Supplementary Fig. S6).

The tablets were surface sterilized in the laboratory by swabbing with $96 \%$ ethanol prior to flushing with 96\% followed by $70 \%$ ethanol, then sterile deionized (DI) water. The sterilized tablets were placed immediately into sterile glass Petri dishes containing $15 \mathrm{ml}$ of sterilized deionized (DI) water, so as not to cover the surface of the tablet, but to saturate the atmosphere with humidity during the experiment, to simulate the high humidity found in typical cave environments. The tablets were left to soak in the sterile DI water for two days prior to inoculation, so that the rock became saturated with water via capillary transport.

\section{Inoculation and biomass estimation}

In the laboratory, the cave waters were sterilefiltered (0.22 $\mu \mathrm{m}$ mesh; Durapore ${ }^{\circ}$, Merck Millipore). In one vial from each site containing the swab tip, $1 \mathrm{ml}$ of the filtered cave water from the corresponding site was added, while $1 \mathrm{ml}$ of sterile physiological saline solution was added to the second vial. The swabs were vortexed vigorously and the solutions with released microbes were placed in new vials. The swabs were then centrifuged for $10 \mathrm{mins}$ at 4,000 RPM to collect the remaining solution and microbial cells, which were then combined with the corresponding solution (cave water or physiological solution) in the "new vials" and used as an inoculum.

The adenosine triphosphate (ATP) contents of these solutions were measured with an AquaSnap ${ }^{\mathrm{TM}}$ Total test using a corresponding luminometer (Hygiena, USA) to estimate the microbial load (Mulec \& Oarga-Mulec, 2016) and approximate the number of microbes in the inoculum, with the caveat that the ATP from lysed cells is counted along with that liberated from living cells. The tablets were arranged so that each tablet would receive one $5 \mu$ drop of microbe-containing solution that was then spread over approximately half of the tablet. The tablets in the Petri dishes were then incubated according to the experimental conditions. Incubation was carried out both at $10^{\circ} \mathrm{C}$, which is approximately the temperature of Postojna Cave, and at $20^{\circ} \mathrm{C}$, thought to enhance the metabolic rate and potentially increase the amount of microbially-mediated precipitation and dissolution, while also representing warmer cave settings. Three cultivation conditions were used: 1) at $20^{\circ} \mathrm{C}$ for two weeks, 2) at $20^{\circ} \mathrm{C}$ for 14 weeks, and 3 ) at $10^{\circ} \mathrm{C}$ (cave temperature) for 14 weeks. For each of these experimental conditions, two Petri dishes were used for each cave site (RD1 or RD5). One dish contained two tablets, both inoculated with material from the cave sites that was re-suspended in (a) filtered cave water or (b) sterile physiological solution. The second dish contained three controls tablets on which were placed drops of (a) sterile DI water, (b) sterile physiological solution, or (c) sterilefiltered cave water from the respective sampling site (Fig. 2).

\section{Tablet surface analysis}

At the end of the experiments, the tablets were observed under a JEOL JSM-IT100 InTouchScope ${ }^{\mathrm{TM}}$ Scanning Electron Microscope (SEM) with Energy Dispersive Spectroscopy (EDS) at the Institute of Palaeontology ZRC SAZU, Ljubljana, Slovenia, to identify possible microbial mediation of calcite dissolution and/or precipitation. To do this, the water was removed from the Petri dishes with a pipette, the tablets were air-dried, and subsequently gold coated using a BAL-TEC SCD 050 sputter coater for $200 \mathrm{~s}$ at $40 \mathrm{~mA}$. The SEM observations were performed under high vacuum, with images collected using a $10 \mathrm{kV}$ accelerating voltage and EDS analyses conducted at 15 or $20 \mathrm{kV}$ accelerating voltage. All types of SEM sample preparation techniques are known to cause artefacts and biases (Fratesi et al., 2004; Bennett et al., 2006). Here, we choose simple air-drying to eliminate potential surface chemical reactions caused by solvent replacement, while maintaining total cell numbers. However, the air-drying technique is known to cause a deflated appearance of cells. Additionally, 
Controls

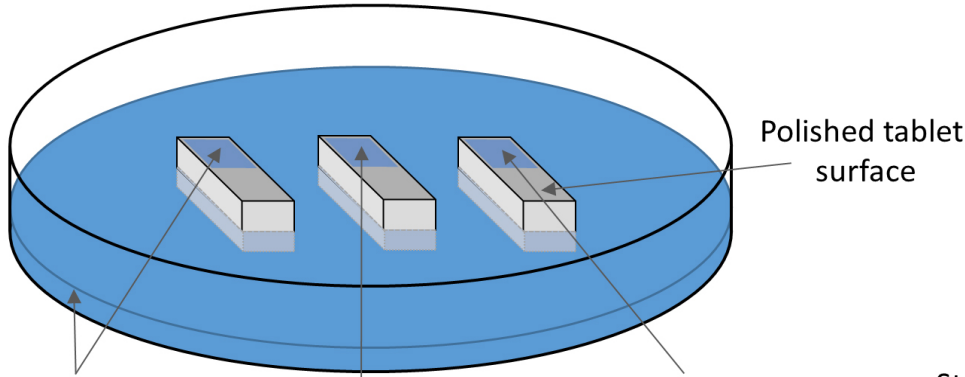

Sterile DI water

Physiological solution
Filtered cave water

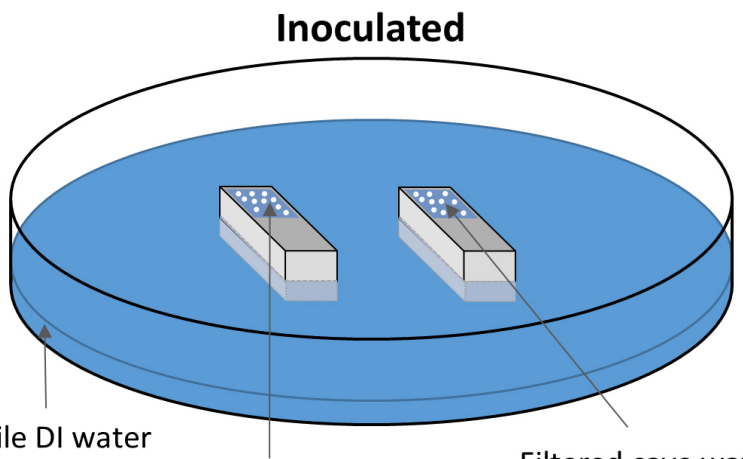

Physiological solution + inoculum
Filtered cave water + inoculum

Fig. 2. Sketch of the experimental set-up. The tablets were placed in Petri dishes with the polished face up, and semi-submerged in sterile DI water. The solution (with or without inoculum) was spread over approximately one half of the tablet surface. Note that for clarity the Petri dish lids have not been drawn on the sketch. Two Petri dishes (as sketched) were used for each cave site (RD1 and RD5), for each of the three experimental conditions, giving a total of 12 Petri dishes used in the experiment.

as the samples were not rinsed to avoid removal of microbes and calcite crystals, mineral detritus could remain on the surface and, moreover, evaporation of water can potentially lead to calcite precipitation (Bennett et al., 2006). This last point is important to assess during interpretations, particularly on the control tablets without microbial inocula, as any observed calcite crystals could, inadvertently, be associated with microbial activity when they may, in fact, be of an inorganic, purely geochemical origin. By comparing the microbial-inoculated tablets with the controls, an assessment of potential inorganic calcite precipitation could be made during the visual inspection for microbes and their association with potential changes to the polished calcite surface.

\section{RESULTS}

\section{Cave water geochemistry}

Table 1 shows the results from a year-long monitoring campaign of the two drip sites carried out to understand how the high variability of cave air $\mathrm{CO}_{2}$ impacts the cave water geochemistry in the dissolution cups. The temperature of the cave air in this chamber is extremely stable, while the temperature of the water in the dissolution cups can vary $\left(<1^{\circ} \mathrm{C}\right)$ when flowing water infiltrates the cave quicker than the time it takes to reach thermal equilibrium with the rock massif. The drip rate at site RD1 is highly variable and goes from practically dry to a fast continuous flow, while site RD5 has a slow but more persistent drip rate. This difference is apparent in the geochemical results that show the conductivity and concentration of major ions in the dripwater from site RD1 as being more 'diluted' by the high flow rates than those values in site RD5. With regard to potential nutrients for microbes, an important difference between the two sites is seen in the nitrate values, whereby site RD5 has a considerably higher concentration of nitrate than site RD1. The calculated calcite saturation indices $\left(\mathrm{SI}_{\mathrm{C}}\right)$ show that the waters change from being slightly under-saturated to moderately over-saturated with respect to calcite, with site RD1 varying over a wider range than site RD5 over the year-long monitoring period. The $\mathrm{SI}_{\mathrm{C}}$, thus, relates to the geochemical changes brought about by the highly variable $\mathrm{CO}_{2}$ concentrations in the cave air over the course of the year (Kukuljan et al., 2021) and the extent to which this $\mathrm{CO}_{2}$ can equilibrate with the infiltration water based on the temporal exposure of the water to the cave atmosphere, which is related to the drip rate, flow style, and cup shape. Dissolved organic carbon concentrations have been previously measured at 33 drip sites in the Postojna-Planina cave system giving an average value of $0.7 \pm 0.04 \mathrm{mg} \mathrm{C} \mathrm{L}^{-1}$ (Simon et al., 2007).

Table 1. Cave water geochemistry from monitoring campaign (13 September 2017 to 13 November 2018).Values in parentheses are those measured at the time of sampling for microbes (date: 18 May 2018).

\begin{tabular}{|l|c|c|}
\hline \multicolumn{1}{|c|}{ Parameter } & Site RD1 & Site RD5 \\
\hline $\mathrm{CO}_{2}$ cave air $(\mathrm{ppm})$ & $630-8300(1969)$ & $650-8230(1969)$ \\
\hline Temperature water $\left({ }^{\circ} \mathrm{C}\right)$ & $8.8-9.6(9.3)$ & $8.7-9.3(9.3)$ \\
\hline Drip rate $(\mathrm{ml} / \mathrm{s})$ & $0.0-1.7$ & $0.004-0.04$ \\
\hline Conductivity $(\mu \mathrm{S} / \mathrm{cm})$ & $205-317$ & $249-398$ \\
\hline $\mathrm{pH}$ & $7.3-8.2(7.8)$ & $7.3-8.0(7.7)$ \\
\hline $\mathrm{Alkalinity}(\mathrm{meq} / \mathrm{L})^{\mathrm{C}}$ & $1.7-3.5(2.9)$ & $2.0-4.2(2.8)$ \\
\hline $\mathrm{Ca}^{2+}(\mathrm{mg} / \mathrm{L})$ & $14-69$ & $34-92$ \\
\hline $\mathrm{Mg}^{2+}(\mathrm{mg} / \mathrm{L})$ & $0.03-2.6$ & $0.02-4.7$ \\
\hline $\mathrm{Cl}^{-}(\mathrm{mg} / \mathrm{L})$ & $0.1-6.5$ & $0.6-11.8$ \\
\hline $\mathrm{NO}_{3}{ }^{-}(\mathrm{mg} / \mathrm{L})$ & $3-10$ & $14-32$ \\
\hline $\mathrm{SO}_{4}{ }^{2-}(\mathrm{mg} / \mathrm{L})$ & $3-5$ & $4-6$ \\
\hline $\mathrm{SI} \mathrm{calcite}$ & $-0.36-0.46$ & $-0.11-0.31$ \\
\hline
\end{tabular}

\section{Microbial biomass in the dripping water}

The bioburden load (i.e., the number of microbes in a given volume of solution; Table 2) shows that the RD1 site had an order of magnitude more microbes than the RD5 site. This means that the number of microbes inoculated onto the tablets for the experiment were considerably greater for the RD1 site. However, this is not necessarily a measure of the total number of microbes at the sampling site because the sampling area was not well-defined due to the rough, undulating inner surface of the dissolution cups (Supplementary Figs S2 and S3). Furthermore, the method used for the estimation of bioburden load theoretically measures the ATP also released from dead cells, thus, our results do not, necessarily, correspond to the number of viable cells present in the inoculum. 
Table 2. Bioburden load of the cave samples.

\begin{tabular}{|c|c|c|c|c|}
\hline Site & Solution & ATP (RLU $\left.{ }^{(1)}\right)$ & $\mathrm{CFU} / \mathrm{ml}^{1(2)}$ & CFU/5 $\mu 1^{(3)}$ \\
\hline \multirow{2}{*}{ RD1 } & Physiological & 22 & $\sim 10^{5}$ & $\sim 500-5,000$ \\
\hline & Cave water & 58 & $\sim 10^{5}$ & $\sim 500-5,000$ \\
\hline \multirow{2}{*}{ RD5 } & Physiological & 4 & $\sim 10^{4}$ & $\sim 50-500$ \\
\hline & Cave water & 6 & $\sim 10^{4}$ & $\sim 50-500$ \\
\hline
\end{tabular}

${ }^{1}$ Relative Light Units (1 RLU equates to $1 \mathrm{fmol}$ of ATP).

${ }^{2}$ Approximate Colony Forming Units (CFU) per ml (Hygiena, USA).

${ }^{3}$ Approximate $\mathrm{CFU}$ inoculated onto each tablet.

\section{Preservation}

The SEM images acquired were of good quality and individual microbes were visible along with the surface of the carbonate tablets in enough detail to investigate possible microbial-mineral interactions. Some microbes were clearly deflated by the drying procedure; however, the majority appeared to have retained their form intact. For this type of experiment, where possible interactions of the rock surface with chemicals used for the preservation of the organic material were unwanted, the procedure of air-drying is shown here to work well in preserving both the rock texture and the microbes. However, one problem with the experimental set-up involved the standing water in the Petri dishes. Using PHREEQC (Parkhurst \& Appelo, 2013), we can show that when DI water (pH 7) is exposed to atmospheric $\mathrm{CO}_{2}$, the dissolution of $\mathrm{CO}_{2}$ in water creates weak carbonic acid, causing the $\mathrm{pH}$ to drop to around 5.5 and the solution becomes aggressive to carbonate rock. We have calculated that this would result in the dissolution of around $8 \mu \mathrm{g}$ of $\mathrm{CaCO}_{3}$, presuming that the water standing in the Petri dish $(15 \mathrm{ml})$ became saturated with $\mathrm{CaCO}_{3}$. However, we suggest that most of this dissolution would occur where the aggressive water first touches the rock; on the external surfaces of the lower halves of the tablets that are submerged in the water and within the porosity and micro-fractures immediately adjacent to this external surface (Fig. 2). If, for example, all the dissolution occurred on the external surfaces of the lower halves of the tablets that were submerged in the water, this would result in the dissolution of a thickness of 0.1-0.2 $\mu \mathrm{m}$ across the submerged surfaces of the tablets. While the $5 \mu$ drop of DI water spread across the upper surface of the tablet would cause a $0.0003 \mu \mathrm{m}$-thickness of dissolution. In the 'Method development' section below, we provide several suggestions to remedy this and other problems found with the experimental design. A second problem involves water droplets condensed on the Petri dish lid and on the tablet surface itself. Some SEM images show circular features of various diameters on the tablet surface that contain tiny calcite crystals (Fig. $3 \mathrm{~A}$ and $\mathrm{B})$. The droplets of condensation, undersaturated with respect to calcite, would have locally dissolved the surface of the tablet and at the end of the experiment, while the tablet was drying, these droplets evaporated, forcing the calcite to precipitate. Minor amounts of calcite precipitation and dissolution were clearly associated with these circular features, seen on both inoculated (Fig. 3A) and control (Fig. 3B) tablets. Nevertheless, our observations show that the minor calcite dissolution and precipitation within these circular features is incomparable to the extent of dissolution and precipitation seen occurring in the presence of microbes elsewhere on the tablets. Moreover, due to the circular shape of these features caused by the droplets, they are clearly distinguishable from other features observed on the tablets. Furthermore, we inoculated approximately one half of each tablet to check the quality of polishing on each tablet and to provide an additional 'control', specific to each tablet. Observing these non-inoculated parts of the tablets, we found that the polishing was uniform and the standard of polishing did not vary across tablets. We also noted that, similar to the control tablets, the non-inoculated parts of the tablets hosted microbes only within or spreading from the micro-fractures (see Discussion), while the majority of these non-inoculated surfaces were unaltered, with the exception of the evaporation circles. Images from each of the experimental setups are shown in Supplementary Figs S6-S19.

\section{Microbial morphotypes and repercussions of rock micro-fractures}

Table 3 shows an assessment of the presence or absence of various features on the tablets for each experimental setup, including the microbial morphotypes (cocci, bacilli, and filamentous) and other inorganic features (calcite precipitation/ dissolution and Si-rich microspheres). To provide a little more information, when a feature was observed on the tablet surface, Table 3 shows also a qualitative estimate of its occurrence frequency as single, rare, customary, frequent, or dominant. Overall, very little of the tablet surfaces were covered with microbes and/or extracellular polymeric substances (EPS), in some cases with only a single example found on the entire tablet surface. Furthermore, when colonies were present, they occurred with varying densities, and their absence/presence (and density) was not found to correlate with the experiment temperature or duration. Due to the very heterogeneous micro-scale distribution of microbes, a systematic grid approach for quantitative analysis would likely poorly represent the microbial activity, which was restricted to localized areas of the tablets, while the majority of the tablets surfaces, including those inoculated, were barren. Our qualitative occurrence frequency estimate in Table 3, thus, provides only an assessment relative to the other tablets in this experiment, rather than on tablet coverage. For example for microbes, dominant may indicate that there was more than one (small) colony present and these were densely populated, while rare may indicate a few isolated microbes found 

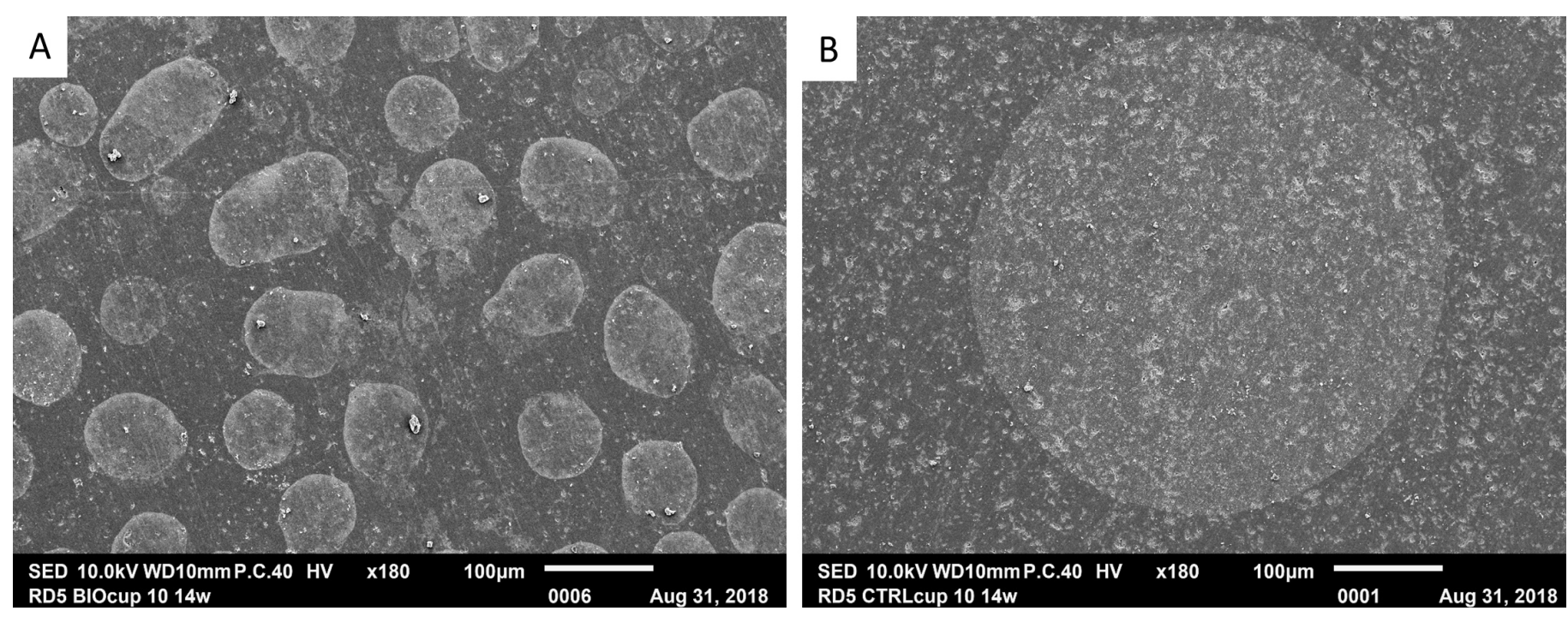

Fig. 3. SEM images of circular features on tablet surface thought to be formed during evaporation of water upon drying. The images are both from the RD5 site, incubated at $10^{\circ} \mathrm{C}$ for 14 weeks; A) cave water with inoculum and B) sterile-filtered cave water. Note that both images are to the same scale and the circular features observed were of varying sizes. The inner, whiter part of the circles contains a high abundance of tiny calcite crystals.

on the tablet surface. As for calcite dissolution, for example, rare may indicate small examples of minimal modification to the tablet surface, while frequent indicates localized patches of highly dissolved limestone showing spiky textures and exposing crystal margins. Although the tablets were composed of an exceptionally homogeneous limestone, since it is a natural substance, many tablets contained some unavoidable heterogeneities (Supplementary Fig. S4), particularly micro-fractures, microstylolites, and other cracks and pores. The SEM images showed that many of the micro-fractures contained microbes (Fig. $4 \mathrm{~A}-\mathrm{D})$. In fact, $42 \%$ of the tablets showed microbes in fractures and there was no significant distinction between those tablets inoculated or the controls (Table 3). The microbes appeared to be emerging from the fractures and then spreading over the tablet surface. This phenomenon was particularly notable in the controls as the rest of the tablet surfaces, away from the fractures, were barren of microbes (e.g., Fig. 4B and C). In one exceptional case (Fig. 4D), fungal hyphae were present and appeared to be emerging from a fracture and spreading over the tablet, in addition to the typical bacterial morphotypes found here. However, some of the wider cracks and larger pores did not host microbes (e.g., Fig. 4B). Of the tablets with the microbes in fractures, $70 \%$ had the presence of cocci morphotype, while 40\% (also) had rod-shaped bacilli forms (Table 3) and in all cases, the microbes from the fractures were associated with EPS.

\section{Calcite dissolution}

The original tablet surfaces were polished and under the SEM appeared flat but with network of straight, polishing scratches visible. These polishing scratches were evenly distributed, less than about $500 \mathrm{~nm}$ in width, and easily distinguishable (blue arrows in Fig. $5 \mathrm{~A}-\mathrm{D})$. The polishing process was required to gain a uniform surface from which the processes of carbonate dissolution and precipitation could be identified easily and not confused with an original, uneven limestone surface that may naturally include zones of dissolution and precipitation. However, polishing also caused some disadvantages, namely, a slick surface rather than the naturally rough surface of a rock, the presence of polishing scratches, and exposure of the internal structure of the calcite crystals rather than the natural crystal faces. The smoothed rock surface is expected to reduce the adhesion of microbes onto the surface, while the polishing scratches may provide preferable locations for adhesion since they provide a protective indentation with a rough surface (Warscheid $\&$ Braams, 2000). However, we saw no evidence of microbes preferentially adhering to the polishing scratches. As for the rock itself, the polishing would have caused a mechanical stress on the carbonate crystals, breaking the crystals in directions that do not correspond to their natural cleavage planes. This unnatural surface may have caused the crystals to become more susceptible to dissolution than a surface comprising natural, well-formed crystals. On the contrary, the polishing may have provided more crystal defect sites that are predisposed to crystal nucleation, hence, increasing the rate of calcite precipitation from that which would occur on a natural carbonate surface. Our tablets are composed of extremely finegrained crystals (see the featureless original tablet surfaces labeled OTS in Fig. 5A-D), and therefore, it is likely that all possible directions of crystals growth were exposed by polishing. This means that there was likely no predominant mechanism at play and, overall, the polishing would have had little influence on whether carbonate precipitation or dissolution occurred. Furthermore, since we are not assessing the rate of the dissolution/precipitation processes here, the effects of polishing are expected to have only a minor influence on our interpretations.

After the experiments, the tablets had various features on their surfaces, including microbes, EPS, particulate matter, etched/dissolved surfaces, and precipitated carbonates. Dissolution of the tablet surfaces was seen as a surface roughening, visible etching around the crystal margins and along calcite cleavage planes, spiky calcite, and widening of polishing scratches to complete obliteration of 


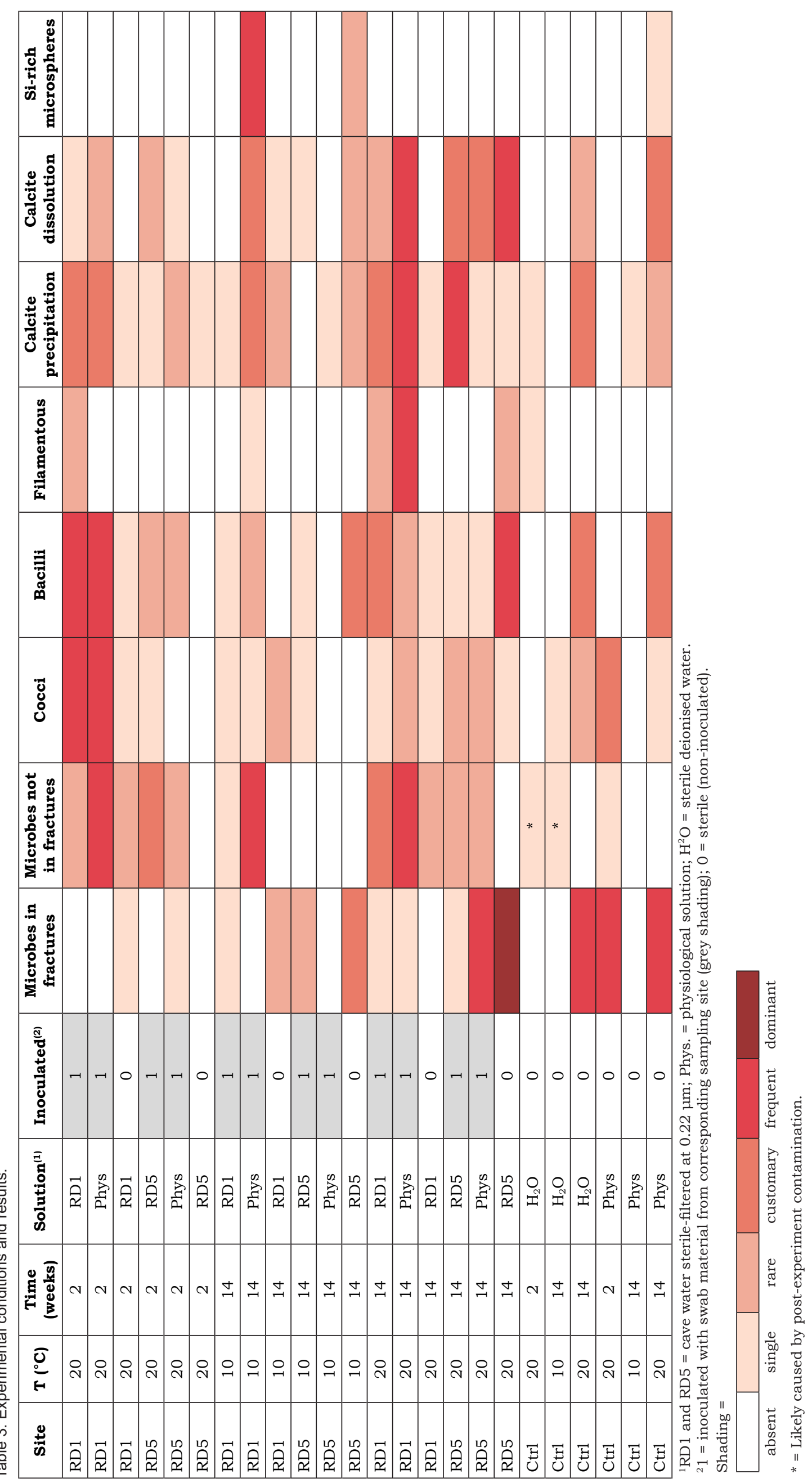



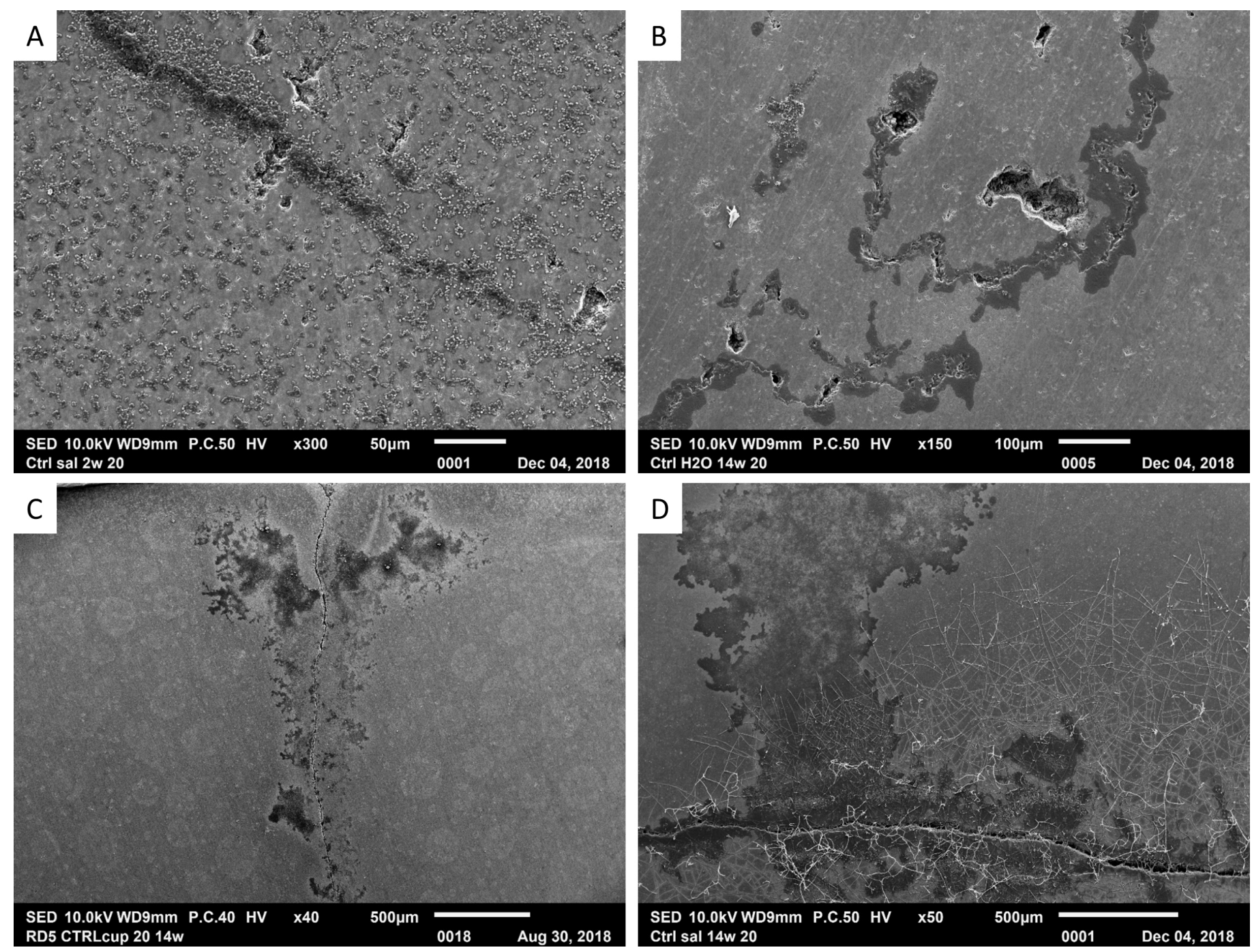

Fig. 4. SEM images showing microbes emanating from pre-existing micro-fractures in the tablets. All examples shown here are from non-inoculated controls at $20^{\circ} \mathrm{C}$. A) Tablet with added physiological solution after 2 weeks. B) Tablet with sterile DI water after 14 weeks. C) Tablet supplemented with sterile-filtered cave water from RD5 site after 14 weeks. D) Tablet with physiological solution after 14 weeks. The images show that the microbes are closely associated with the micro-fractures but not within the wider pores, and microbes are not present on the rest of the tablet surfaces, away from the cracks.

polishing scratches and the original surface under heavy dissolution. Microbes and EPS were seen in association with tablet dissolution (notably on Fig. 5A and D). On lower magnification SEM images (Fig. 5A-D), the EPS and microbes appear as darker shades, while the exposed areas of dissolution appear as lighter shades due to the enhanced surface roughness and, in some cases (such as Fig. 5B) consequent calcite precipitation. Under higher magnification, the dissolution is clearly visible as etched and spiky calcite (Jones \& Pemberton, 1987) (Fig. 6A-D). Dehydrated EPS can be seen within some pore spaces (e.g., Fig. 6B and D), indicating a strong association between the presence of dissolution and EPS. Of all the tablets, $63 \%$ showed some dissolution and, in all cases, this dissolution was associated with tablets that had EPS and the presence of microbes (Table 3).

\section{Calcite precipitation}

Calcite crystals on the surface of the tablets could have been derived from a number of processes. Detrital calcite could have been picked up on the swab from the cave surface, and transferred with the microbes to the tablet surface. We might expect detrital calcite to be anhedral in shape and perhaps associated with clays or other particles lying on the tablet surface, while precipitated calcite likely interacts with the tablet surface and perhaps forms as euhedral crystals. Precipitated calcite could derive from purely chemical processes or through microbiological mediation. Chemically, the calcite could precipitate from the various solutions upon evaporation during drying at the end of the experiment. It could be sourced directly from the cave water itself or from dissolution of the tablet surface by solutions under-saturated with calcite (e.g., DI water and physiological solution). This can be seen in Figures $3 \mathrm{~A}-\mathrm{B}$ and $4 \mathrm{C}$ as circular features covering the tablet surface, where the inside of the circle contains calcite crystals likely formed on drying. In the case of microbially-mediated calcite, the precipitated calcite should be more common in areas with microbes.

Various types of calcite precipitation on the tablet surfaces are shown in Figure 7A-D. The forms shown are predominantly euhedral and are all associated with microbes or EPS. In Figure 7A, the tablet surface affected by microbes appears to have been dissolved, giving a rough surface from which calcite crystals have formed following the cleavage direction of the original 

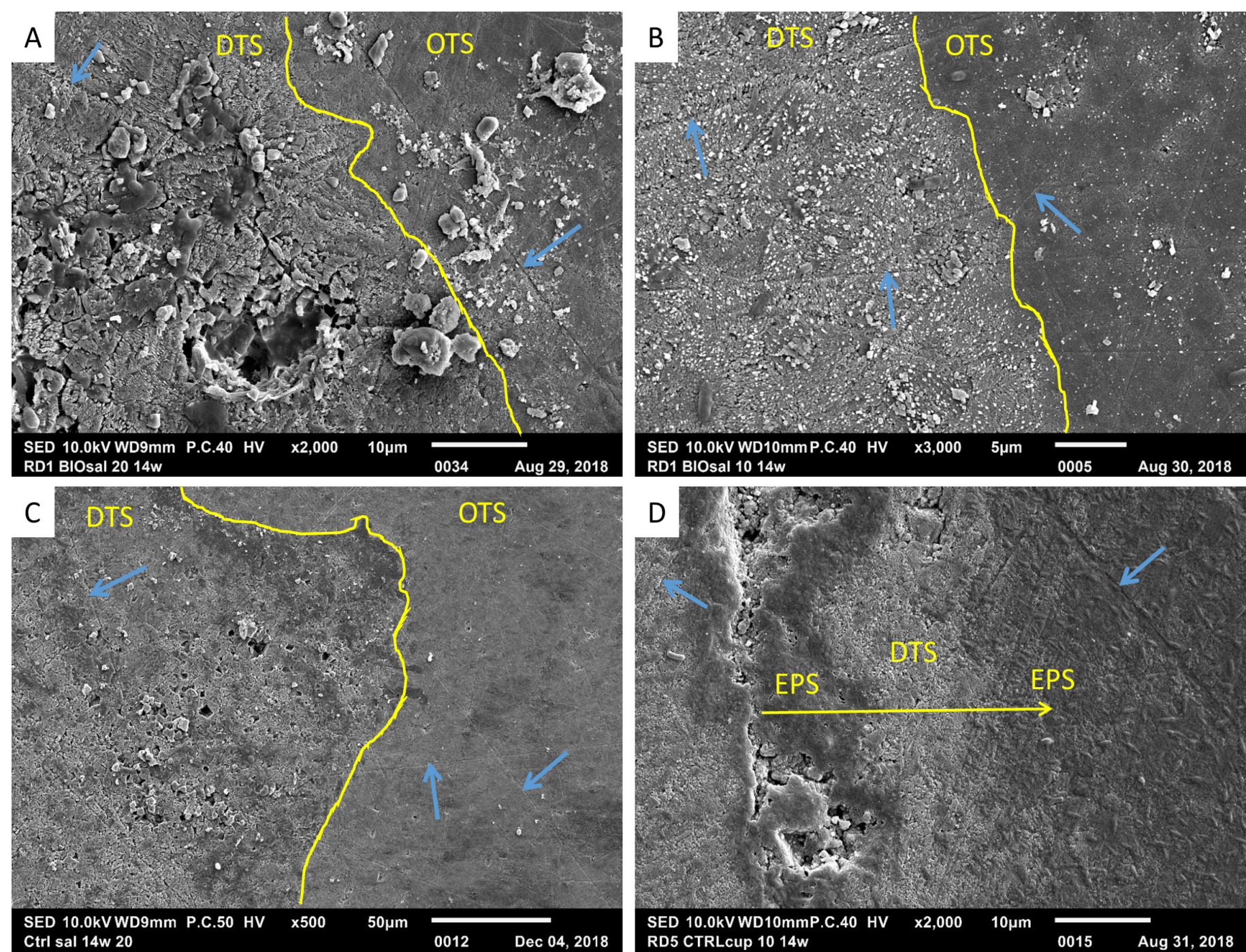

Fig. 5. SEM images of tablet dissolution at lower magnification. A and B) Tablets inoculated with material from site RD1 in physiological solution after 14 weeks at (A) $20^{\circ} \mathrm{C}$ and $(B) 10^{\circ} \mathrm{C}$. C) Control using sterile physiological solution after 14 weeks at $20^{\circ} \mathrm{C}$. D) Control using sterile-filtered water from site RD5 after 14 weeks at $10^{\circ} \mathrm{C}$. In A-C, note the difference in tablet surface texture between the original tablet surface (OTS) towards the right-hand side and the modified dissolved tablet surface (DTS) and presence of microbes on the left-hand side. In D, note the presence of microbes and EPS, and an area between these, over which the microbes passed while gliding away from the crack (direction of yellow arrow), where the dissolved tablet surface has been exposed. Blue arrows point perpendicular to selected polishing scratches.

calcite crystals in the rock. In Figure 7B, a microfracture hosting thick EPS and microbes exhibits a high density of euhedral calcite crystals of varying sizes within and protruding out of the fracture, some entrapped under the EPS, while others are exposed above the EPS. There is a notable difference in the high number of calcite crystals associated with the EPS covered fracture and the lack of crystals on the tablet surface away from the fracture. Figure $7 \mathrm{C}$ shows a colony of microbes associated with a number of flat, euhedral calcite crystals. Furthermore, a number of smaller euhedral calcite crystals appear to be forming as prisms directly associated with the microbes. Figure 7D shows a micro-fracture that is filled by EPS and microbes, along the edge of this fracture, large euhedral calcite crystals have formed that protrude from the polished tablet surface, indicating they formed during the experimental period.

\section{Si-rich microspheres and microbial entombment}

Three tablets showed a specific feature composed of microspheres (Fig. 8A-D). These microspheres are a relatively uniform size ( $250 \mathrm{~nm}$ diameter $)$, densely packed, and their composition by SEM-EDS shows them as being rich in silicon (Supplementary Fig. S20). These Si-rich microspheres appear to be intimately associated with microbes (Fig. 8A). In certain places, it appears that the spheres are merging to form larger particles (Fig. 8A). Additionally, these forms are associated with the precipitation of stepped-rhombohedral crystals of calcite (Fig. 8A and B). Most remarkably, they appear to be entombing bacilli, producing casts (Fig. 8B-D). In common, these microsphere-features form in depressions or at the margin of cracks in the original host-rock, tending to infill the space.

\section{DISCUSSION}

The presence of microbes in micro-fractures, particularly on the control tablets, demonstrates that wiping and flushing with $96 \%$ and $70 \%$ ethanol did not ensure complete sterilization of the substrates and ensure microbe-free tablets before the experiment. We speculate either that the tablet surfaces were not exposed to the ethanol for a long-enough time (approximately $10 \mathrm{~s}$ ) or that the ethanol did not penetrate deep enough into the micro-fractures. 

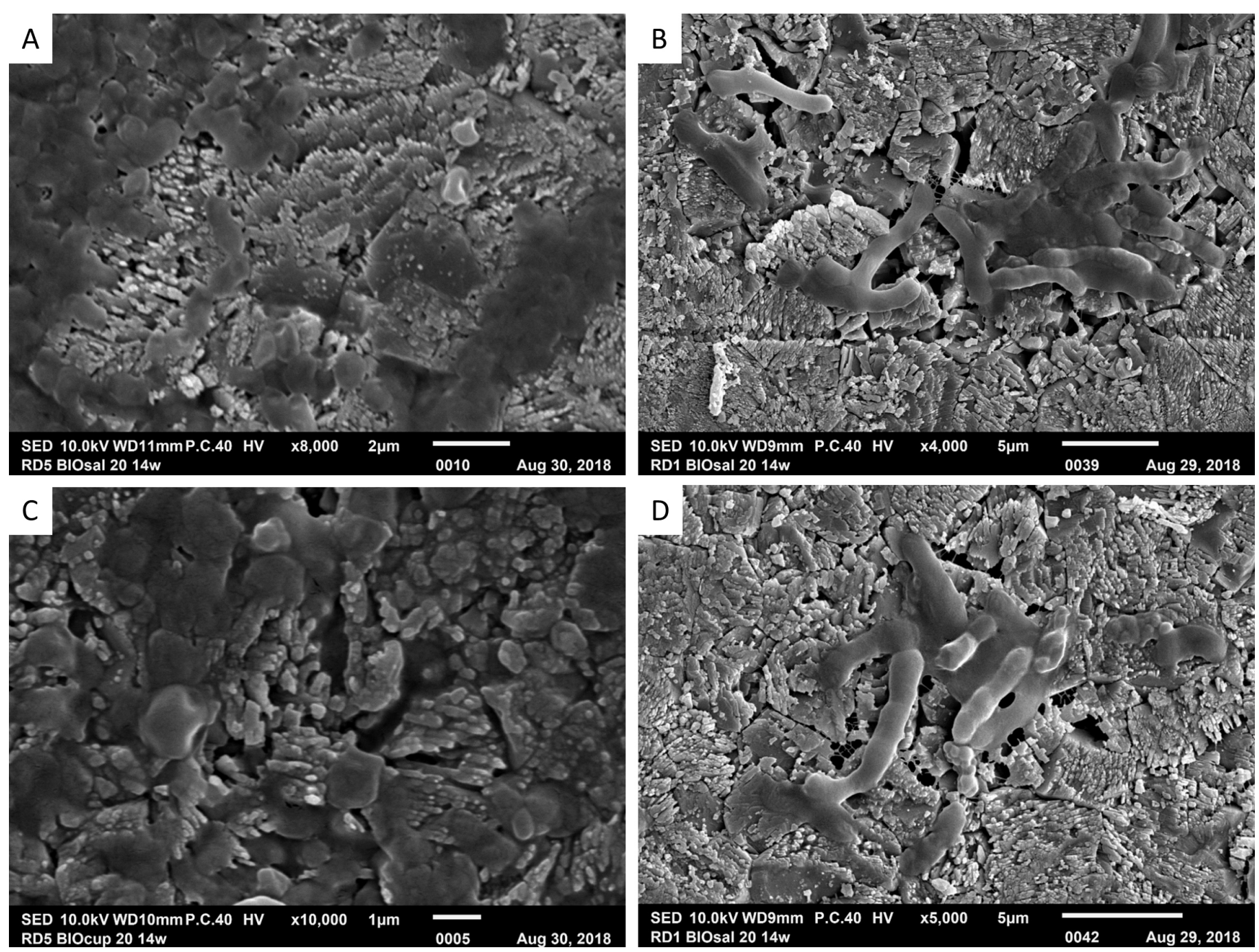

Fig. 6. SEM images of tablet dissolution at high magnification. All images after 14 weeks at $20^{\circ} \mathrm{C}$. A and C) Inoculated with material from site RD5 in (A) physiological solution and (C) cave water from the same site. B and D) Inoculated with material from site RD1 in physiological solution. In all images, note the presence of microbes and EPS. The original, polished tablet surfaces have been strongly modified and show spiky calcite and clear etching of the crystal margins and calcite cleavage planes.

Alternatively, the $96 \%$ ethanol may have entered the micro-fractures and rapidly denatured the proteins in the cell walls of the microbes, effectively sealing the cells to further penetration of alcohol, inactivating the microbe but non-lethal. The presence of the $96 \%$ ethanol then blocked the entry of the $70 \%$ ethanol into the micro-fractures; the $70 \%$ ethanol is a more effective antimicrobial agent due to the optimum osmotic pressure, thus, the slower penetration of ethanol into the cell interior that kills the microbe. As a result, subsequent re-growth of the inactivated cells deep within the micro-fractures could occur once the sterilizing agent was no longer present. We had decided against autoclaving the tablets due to potential artefacts of the substrates and the fear that the humid environment during this sterilization process would create a weak carbonic acid when $\mathrm{CO}_{2}$ dissolved in the steam/condensation that could have caused carbonate dissolution, followed by re-precipitation, on the tablet surface. Due to what appears to have been an incomplete sterilization by the ethanol method used here, we cannot assume that all microbes present on the tablets were derived from the cave, and thus, we cannot draw robust conclusions regarding the activity of cave-specific microbes on limestone. However, it is possible to gain some insight into the interactions of microbes, in general, on limestone surfaces under our experimental conditions. In our experiment, we decided to use physiological solution besides cave water to mimic strict oligotrophic and starvation conditions, while avoiding osmotic stress, to observe the differences with cave water that contains low, but not negligible concentrations of nutrients. The results indicated no clear differences if these two media were used along with the microbial inoculum, despite cave water containing some dissolved organic matter (Simon et al., 2007). This organic material can play an important role as a source of nutrients for cave microbes (e.g., Shabarova et al., 2014). Successively, the simplified airdrying procedure used in the study was proven to give sufficient information on microbe-host-rock interactions, without the procedure itself grossly affecting the rock surface. Here, we focus on the processes of microbiallymediated calcite dissolution and precipitation and the mobilization of Si-rich minerals. We have used the term microbially-mediated as a general term that may include both active or passive microbial metabolic processes that affect the dissolution and precipitation of calcite. Particularly, in the observed calcite precipitation processes, it is difficult to assess if the mineralization is actively caused by the microbes (microbially-induced, Dupraz et al., 2009) or related to the environmentally 

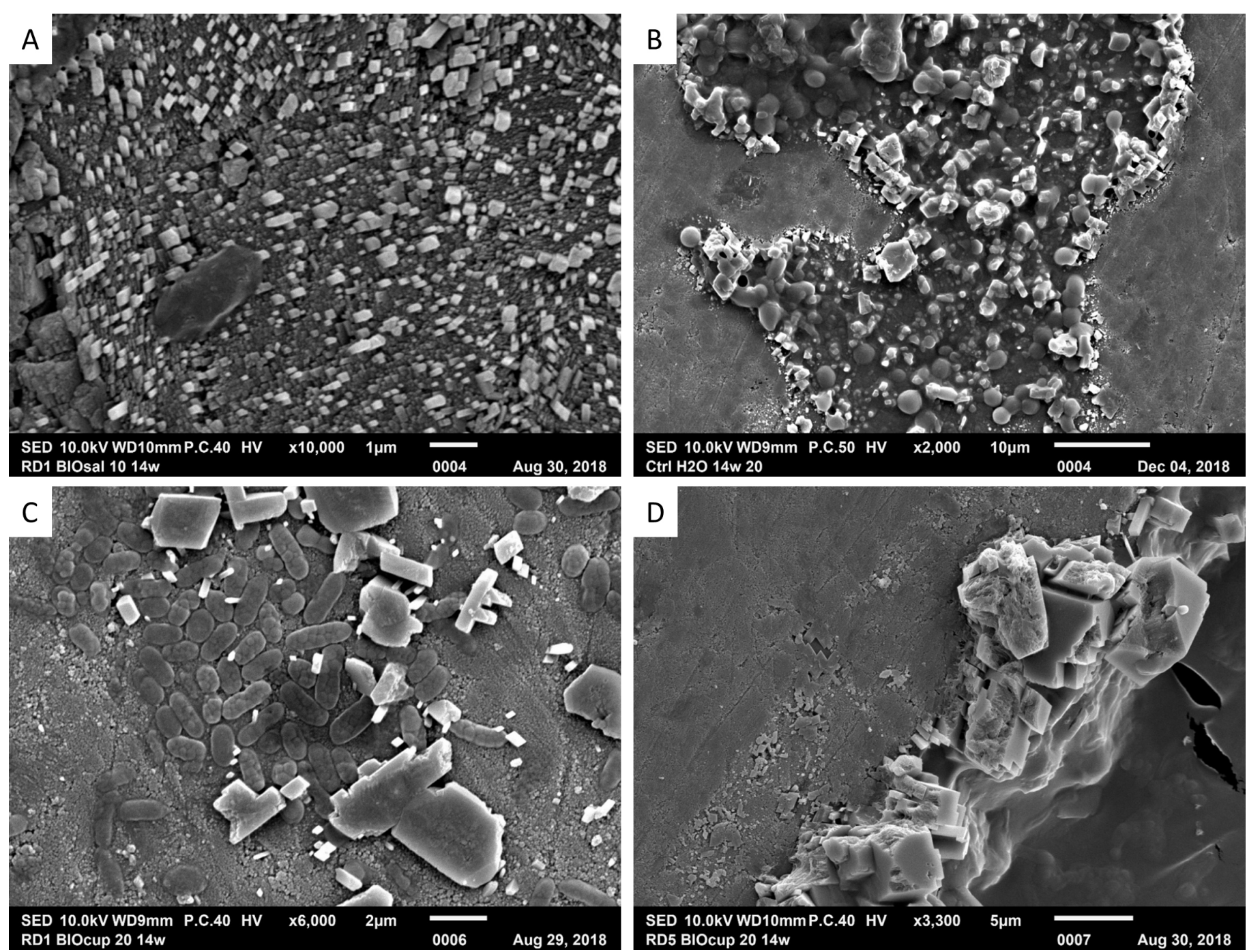

Fig. 7. SEM images of calcite precipitated on tablet surfaces. A) Inoculated with material from site RD1 in physiological solution after 14 weeks at $10^{\circ} \mathrm{C}$. B) Sterile DI water after 14 weeks at $20^{\circ} \mathrm{C}$. C) Inoculated with material from site RD1 in natural water from the same site after 14 weeks at $20^{\circ} \mathrm{C}$. D) Inoculated with material from site RD5 in natural water from the same site after 14 weeks at $20^{\circ} \mathrm{C}$. Note the euhedral shape of the calcite crystals protruding from the original polished tablet surfaces, indicating that they have been precipitated during the experiment in association with microbes and EPS.

driven mineralization of EPS (microbially-influenced, Dupraz et al., 2009), so we have avoided the use of these terms here.

The microbes seen within micro-fractures may have entered these fractures either while the rock was in the natural setting (endoliths), during extraction, storage and transport, or during the preparation for the experiment. The preparation involved cutting and polishing the rock using tap water as a lubricant, which could have forced polishing powder and dust into the cracks along with unsterile water. These processes could have easily allowed microbes to enter deep into the fractures and provided humidity, allowing growth. However, the tablets were air-dried and stored for around one month before initialization of the experiment, indicating that the types of microbes present must have survived such conditions for an extended period of time, deep in the fractures, and were then able to survive the surface sterilization using ethanol within these micro-fractures. Some observed morphotypes could be also considered as bacterial spores, such as Bacillus spores, which are known for their higher tolerance against harsh environmental conditions (e.g., desiccation) and for long-term survival in alcohol (Thomas, 2012).
On $75 \%$ of the inoculated tablets, microbes were found scattered on the tablet surface, disassociated with fractures. It is possible that these microbes derive from the cave, while the microbes within microfractures survived the sterilization process, hence, were not necessarily cave microbes. However, there were five control tablets where microbes or possible organic features were also visible in areas away from any obvious fractures (Table 3); we now explain our suspected origin of these particular microbes. Two of these control tablets involved the cave water from the $\mathrm{RD} 1$ site, both at $20^{\circ} \mathrm{C}$ ( 2 and 14 weeks), and showed a relatively high abundance of microbes away from the micro-fractures (Supplementary Figs S6E and F, and $\mathrm{S} 11 \mathrm{E}$ and F). On these tablets, however, we notice a number of small spherical forms that appear to be of a microbial origin. From this, we suggest that these small spherical forms possibly represent a starvation morphology that were small enough to pass through the $0.22 \mu \mathrm{m}$-mesh filter (Hahn, 2004; Männik et al., 2009) and, thus, are derived from the cave water. Some of these individuals could be affiliated with nanobacteria; a group of single cell organisms smaller than $200 \mathrm{~nm}$ (Vainshtein \& Kudryashova, 2000). Alternatively, they could have derived from the 

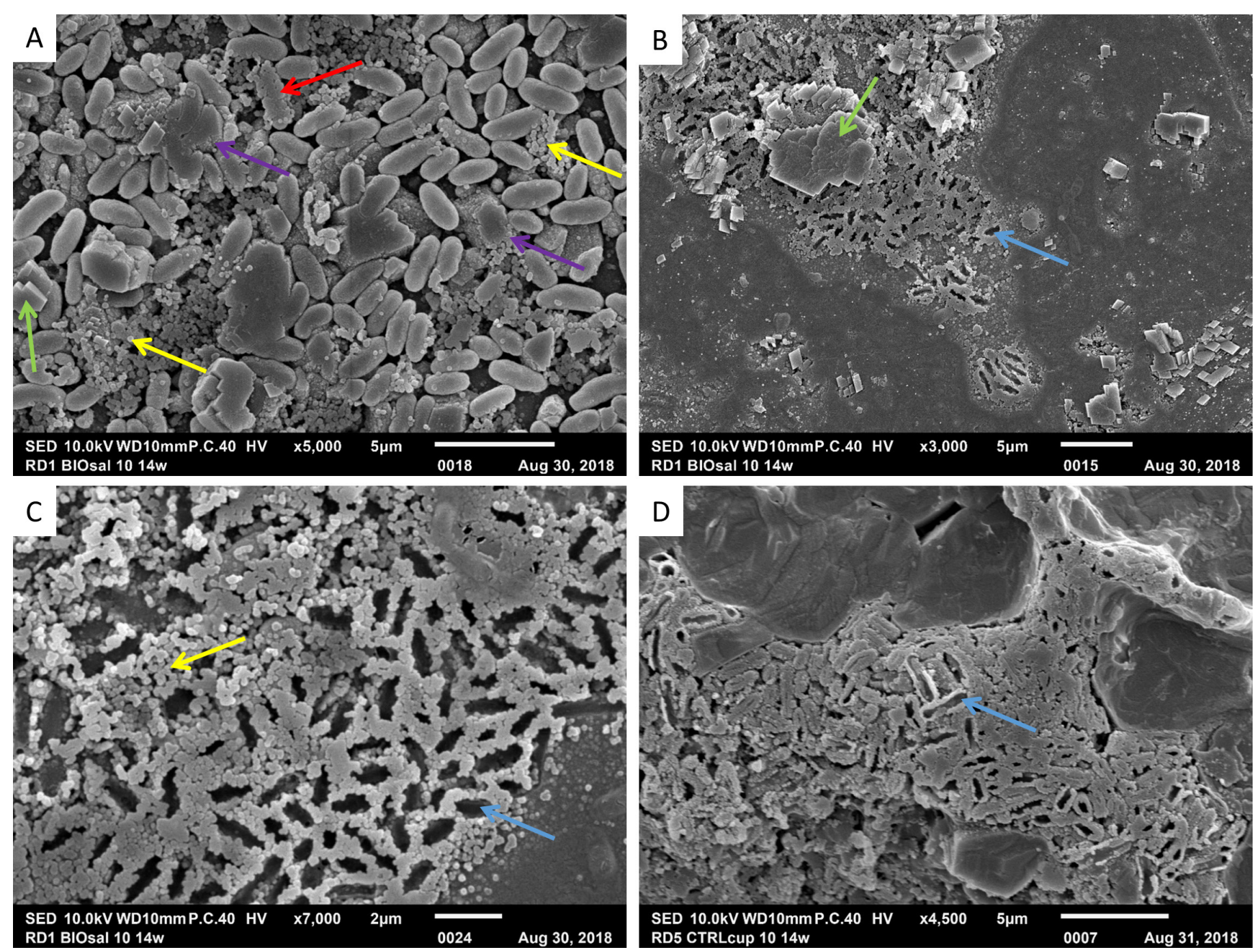

Fig. 8. SEM images of areas of the tablets that contain Si-rich microspheres and microbe casts. A-C) Tablet inoculated with material from site RD1 in physiological solution at $10^{\circ} \mathrm{C}$ after 14 weeks. D) Control using sterile-filtered water from site RD5 after 14 weeks at $10^{\circ} \mathrm{C}$. Arrows indicate examples of: yellow $=$ Si-rich microspheres, red $=$ microbe becoming entombed by microspheres, purple $=$ microspheres coalescing to form larger particles, green $=$ stepped-rhombohedral calcite crystals, and blue $=$ casts of bacilli within the microspheres .

micro-fractures and have glided a significant distance over the tablet surface in search of a proper niche to form new colonies elsewhere. However, in these two cases, we observed no large micro-fractures hosting microbes on the tablet surfaces, hence, we believe that the microbes derived from the cave water. On a different control tablet, this time with the physiological solution (at $20^{\circ} \mathrm{C}, 2$ weeks), microbes were also found away from the micro-fractures. There were high abundances of microbes in micro-fractures on this tablet that appeared to be spreading a significant distance from the micro-fractures (Supplementary Fig. S6C and D), and so it is most likely that the microbes glided further away from these fractures, forming new, small colonies during the experiment. The other control tablets to host microbes/biological material away from the fractures were the DI water controls ( 2 weeks at $20^{\circ} \mathrm{C}$ and 14 weeks at $10^{\circ} \mathrm{C}$ ). However, in these two cases, one is noted as a single large coccus morphotype (exceptionally large compared with those seen elsewhere in this experiment; Supplementary Fig. S16B) and the other as single organic-looking particle (not necessarily microbial) that does not appear to have any relationship with surface processes (Supplementary Fig. S16D). In these two, exceptional cases with only one possibly microbial particle on an otherwise barren tablet, we attribute these forms to post-experiment contamination, for example, as particles from the air settling on the tablets possibly during drying or transfer to the gold coater/SEM.

All of the tablets inoculated with material from the RD1 site showed the presence of microbes that were not associated with micro-fractures, and relatively high amounts of EPS. Whereas, in only two-thirds of the tablets inoculated with RD5 site material, microbes were observed away from micro-fractures. This is perhaps related with the lower number of microbes in the inoculum that may reflect a reduced biomass at the RD5 site (Table 2). Different microbial communities are possibly affected by the diverse hydrological characteristics of the two drip sites and their corresponding pools of water inside the cups. The two drip sites are $\sim 2 \mathrm{~m}$ apart, and thus, dripwater is likely derived from the same soil and epikarst zone, hence, likely provides a similar community of microbes to the cave pools. However, site RD1 has a flashy drip rate that responds rapidly and intensely to rainfall events but will dry-up during dry periods, whereas, RD5 has a more constant drip that continues, albeit slowly, even during dry periods, maintaining a pool of water at the sampling site. Previous research has 
shown that highly variable flow rates that respond rapidly to recharge tend to provide more nutrients to a cave pool, than found with a lower and more constant flow rate (Shabarova et al., 2014). This is likely due to the rapid fracture flow bringing more organic matter into the cave, while the host-rock matrix filters much of these particles out of the water arriving at matrix-flow drip sites (e.g., Shen et al., 2015; Blyth et al., 2016). The greater nutrient supply to the RD1 (fracture flow) site at the time of sampling (with active flow), perhaps permitted the higher biomass observed in the RD1 samples, than in the RD5 samples. While the sporadic nature of the RD1 fracture flow, may lead to a different microbial community more adapted to periods of desiccation and depleted nutrient supply (characteristic of r-strategists), in comparison with those adapted to the more stable conditions at the RD5 site (characteristic of K-strategists).

The results showed that the quantity of inoculum used and a 2-week incubation period were already enough to observe microbial replication, active gliding, the initial stages of microbial colonization, and microbe-rock interactions, in terms of calcite dissolution and precipitation. The interactions were clearer after prolonged incubation of 14 weeks and at the higher cultivation temperature $\left(20^{\circ} \mathrm{C}\right)$ but still no multi-layered structures typical of maturing biofilm were observed. However, the cultivation temperature did not show evident differences in formation of mineral diversity.

Areas of intense dissolution of the tablet surfaces were found associated with microbial presence and/or activity (Fig. 5A and D and Fig. 6A-D). The presence of EPS was commonly related with dissolution, indicating a compelling impact of microbes on the host-rock. However, we believe much of the dissolution expected to be observed under SEM may have been masked by thick EPS and microbial colonies, particularly those associated with the micro-fractures, where the limestone surface in contact with the microbes was not often visible (e.g., Fig. 5D). In areas where the EPS has been lost or dehydrated/shrunk, the dissolved tablet surface becomes visible. In such areas, the surface showed increased roughness (Fig. 5A-D), etching along crystal margins and spiky calcite (Fig. 6A-D). Due to the strong association between the areas with microbes and the strong dissolution, we can infer that this dissolution was microbially-mediated. Microbial dissolution is known to occur due to the formation of metabolic organic acids (Bullen et al., 2008), enhanced $\mathrm{CO}_{2}$ from microbial respiration that modifies the $\mathrm{pH}$ (Portillo \& Gonzalez, 2010), enhanced water-retaining properties of the biofilm (Lian et al., 2008), and to the presence of EPS (Perry et al., 2004; Krause et al., 2014). A benefit of limestone dissolution to the microbial community includes the release of essential minerals for microbial metabolism, for example, trace elements, such as $\mathrm{Al}, \mathrm{Ba}, \mathrm{Cd}, \mathrm{Co}, \mathrm{Cu}, \mathrm{Fe}, \mathrm{K}$, $\mathrm{Mg}, \mathrm{Mn}, \mathrm{Na}, \mathrm{Si}, \mathrm{Sr}, \mathrm{Ti}, \mathrm{U}$, and $\mathrm{Zn}$, found in carbonate rocks (Morse \& MacKenzie, 1990). In addition to microbially-mediated dissolution, some purely geochemical dissolution is likely to have occurred when using DI water and physiological solution as these would have been under-saturated with calcite. It is also possible that the sterile DI water sitting in the Petri dish seeped into the rock via capillary flow. In this case, however, we would expect the dissolution to occur near the base of the tablet where the water first encounters the rock, at which point it would quickly become saturated with carbonate relative to the slow rate of capillary transport, hence, dissolution associated with this would not affect the surface of the tablet being studied. Furthermore, sample liquids were spread over the limestone surface. These would have quickly reached saturation with carbonate dissolving the whole surface of the rock in a relatively uniform manner, where the amount dissolved corresponds to a $0.0003 \mu \mathrm{m}$-thickness of dissolution. Due to the large surface area of the tablet exposed to these liquids compared with the extremely localized areas in which both microbes and high amounts of dissolution were found, we are confident that our interpretations relating to microbially-mediated dissolution are correct and not a purely geochemical effect. Moreover, this possible surface dissolution caused by the inoculating solution being undersaturated with respect to calcite would not have been the case with the cave water, which was likely already at calcite saturation in the cave (as it was in contact with limestone on collection). On leaving the cave, the lower atmospheric $\mathrm{CO}_{2}$ concentration would have caused $\mathrm{CO}_{2}$ degassing, forcing the liquid to become saturated with calcite. Therefore, the highly localized areas of intense limestone dissolution, particularly on the tablets where cave water was used, must have been significantly influenced by microbial activity.

In addition to calcite dissolution, calcite precipitation was also observed, with the most abundant and largest crystals in association with microbes and EPS. In terms of conservation of mass, $\mathrm{Ca}^{2+}$ ions released during microbially-mediated dissolution would react with metabolic products of the microbes $\left(\mathrm{CO}_{3}{ }^{2-}\right)$, forming microbially-mediated $\mathrm{CaCO}_{3}-$ which may or may not be microbially-induced (Dupraz et al., 2009). Moreover, large crystals were observed within/covered by EPS, and hence, formed during the experiment (rather than via geochemical precipitation during drying). A study of bacteria isolated from a Hungarian Cave has shown that cave bacteria are capable of forming and stabilizing amorphous calcium carbonate (ACC) in association with EPS. This ACC, which is a precursor to crystalline calcium carbonate, can then crystalize into calcite when water penetrates the protective EPS layer (Tünde Enyedi et al., 2020). Hence, we expect the close association between bacteria, EPS, and calcite crystals, as found in our experiment, and suggest that oligotrophic conditions in caves may contribute to the breakdown of the protective EPS layer, promoting calcite precipitation from the ACC precursor. Other research has shown that organogenic calcite morphologies grown in liquid enrichment culture medium were often found to be rhombohedral, elongated, spindle-shaped, or even semi-spherical crystals, rather than the large, stepped-rhombohedral aggregates with sharp corners of abiotic calcite (Zhuang et al., 2018). While another 
culture experiment demonstrated that the morphology and size of calcium carbonate crystals related to the specific bacterial strain (Li et al., 2018). Similarly, a different study, using bacteria isolated from a cave incubated in liquid medium, showed carbonate crystal morphologies, varying from rhombohedral to globular, to be taxon-specific (Rusznyák et al., 2012). $\mathrm{CaCO}_{3}$ deposits observed within microbial colonies removed from Altamira Cave, Spain, that were interpreted as being bio-precipitated, comprised of rhombohedral crystals arranged with rosette or nest shaped morphologies, and spheroids that were inferred as vaterite (Cuezva et al., 2009). Here, we found the precipitated calcite to be mostly rhombohedral. We suggest the possibility that the species of bacteria present, combined with the low nutrient levels and high $\mathrm{pH}$ may be responsible for the crystal morphologies observed. Furthermore, the presence of the rock could provide a template for nucleation of rhombohedral forms, not present in liquid culture medium, and may have caused preferential carbonate formation with rhombohedral morphologies. In summary, we infer that the carbonate crystal observed in association with microbes and EPS were microbially-mediated.

An interesting precipitate found on the tablets consists of tiny $(\sim 250 \mathrm{~nm}$ diameter $)$ spheres with a unimodal size distribution that tend to entomb microbes (Fig. 8A-D). We exclude these as being ACC because ACC spheres typically have diameters of $\sim 30 \mathrm{~nm}$, with a critical upper limit of $\sim 120 \mathrm{~nm}$ (Pouget, et al., 2009), hence, are much smaller than the spherical forms observed here. Furthermore, the SEM-EDS analyses showed that areas including these spherical forms are composed of $\mathrm{Si}$, in addition to $\mathrm{Ca}$, $\mathrm{C}$ and $\mathrm{O}$ (Supplementary Fig. S20), which were likely derived from the surrounding/underlying calcite tablet surface $\left(\mathrm{CaCO}_{3}\right)$, organic matter (comprising $\mathrm{C}$ and $\mathrm{O}$ ) and $\mathrm{O}$ forming silicate (e.g., $\mathrm{SiO}_{2}$ ). Since these spherical forms are found in depressions and cracks on the tablet surface and that negligible $\mathrm{Si}$ is expected to derive from the cave water or inoculate, we suspect that the initial source of Si comes from Si-rich impurities in the limestone tablets. Alternatively, the Si could have been sourced from the polishing paper used in sample preparation; however, any grains should have been removed during swabbing and flushing with ethanol during sterilization. Our images show that these Simicrospheres could attach and fuse to the microbes and were actively coalescing to entomb the microbes during the experiment (Fig. 8A), ultimately producing casts (Fig. 8B-D). Such attachment and coalescing of Si-rich particles to microbes has similarly been found when experimentally synthesizing Si-nanocomposites using Actinobacter sp. (Li et al., 2016) and in hydrothermal sinter deposits (Konhauser, 2016). During our experiment there was no purelygeochemical potential to mobilize silica, and since there was active Si-particle fusing causing the microbes to be entombed, we can infer that the Si-microsphere formation was occurring during the experiment and, therefore, must have been microbially-mediated. The formation of Si-microspheres under neutral $\mathrm{pH}$ conditions and ambient temperatures, with a minimal
Si source could have important implications for industrial Si-nanoparticle production. The possibility of such environmentally-friendly biosynthesis has many industrial applications including drug delivery, production of resins, catalysts and pigments, and thermal or electrical insulators (Li et al., 2016). Furthermore, the potential for ambient-conditionadapted microbes to be preserved in the stable silica mineral-form could widen the potential for discovery of microbial life in early Earth's history and on other planets, such as Mars. Moreover, the formation mechanism of large cave systems formed in low-solubility orthoquartzite is highly debated given the slow solution kinetics of silica under neutral to slightly acidic $\mathrm{pH}$ conditions and has been proposed to be influenced by silica-mobilizing bacteria (Sauro et al., 2018). In addition, such caves host silica 'biospeleothems' that have been shown as biologically mediated and have potential as palaeoclimate archives (Lundberg et al., 2018) but the environmental conditions under which they form are yet undefined. Our findings indicate here, for the first time, that cave microbes under oligotrophic conditions could mobilize silica under ambient conditions, including neutral $\mathrm{pH}$, in controlled laboratory conditions in short (weeks) time periods. Since our microbes were taken from a simple limestone cave, and not specifically one associated with large-scale Si-mobilization, this may indicate that microbes with the potential to mobilize silica under ambient conditions are far more widespread than currently thought. Microbiallyassisted mobilization of silica may be an overlooked mechanism under ambient conditions that may be prevalent throughout Earth's crust, and thus, has strong implications for our understanding of the global weathering cycle.

\section{METHOD DEVELOPMENT}

Throughout this research, we have attempted to identify the limitations caused by our experimental methods and considered how these may have influenced our results and interpretations. We admit that the experiment did not achieve our original research goal to study cave specific microbes, however, it tentatively provides some insight into microbial interactions with limestone. More valuably, we outline the many problems encountered with our experimental set-up and we aim to provide some possible resolutions to these problems. This will allow future research to be carried out with improved methods and reduced misinterpretation; overall, pushing forward this important field of research in the most robust manner possible.

The first problem involved the rock composing the tablet. Although the bulk rock texture was homogeneous (Supplementary Fig. S4), and even under SEM we observed a consistent grain size containing very few fossils, recrystallized areas, or visible pores, the presence of micro-fractures caused major problems. Natural rock samples inherently contain heterogeneities, however, future studies may consider using a different limestone, such as the Upper 
Jurassic Solnhofen Limestone, a freshly-cleaved calcite ('Iceland') spar, or alternatively, a synthetic, precipitated calcium carbonate. Furthermore, a prescreening of each tablet may permit those with microfractures to be discarded. A different approach might consider attempting to infill the micro-fractures with epoxy resin, or similar, and re-polishing the samples. However, it is unlikely that this would be universally effective due to the thinness of the micro-fractures.

Next, the sterilization of the tablets appears to have been incomplete. We had considered various sterilization techniques, but we decided on ethanol sterilization because we wanted to preserve the integrity of the limestone substrate as much as possible. Use of other chemicals could have impacted the tablets significantly on the micro-scale, for example, one option could be hydrogen peroxide, but in this case the sterilization is based on the oxidation reaction and this could interfere with (oxidize) the tablets or potential impurities within the rock. Chemicals containing benzalkonium chloride, or similar, may be more problematic, reacting with the rock surface via charged radicals. Autoclaving, flaming, and dry heat were considered too drastic, as they might have interacted with the limestone and changed the texture of the surface on a micro-scale. However, investigations after the experiment had been completed have now shown that autoclaving did not affect majorly the polished limestone surface and produced only a few, presumably carbonate, crystals of varying dimensions (Supplementary Fig. S21), possibly removable by flushing with sterile DI water (un-tested). Therefore, autoclaving would likely be the sterilization method of choice for further investigation of microbial interactions with rock surfaces.

The next set of problems involved the sterile DI water placed in the Petri dishes. This water would react with atmospheric $\mathrm{CO}_{2}$ to produce a weak acid, becoming aggressive to the carbonate tablet, which may be transported to the studied surface via capillary transport. Buffering the $\mathrm{pH}$ of this water to neutral after it had reached $\mathrm{pCO}_{2}$ equilibrium with atmospheric $\mathrm{CO}_{2}$ would solve this problem. Using sterilized water collected from the cave could be a good alternative option. It would also be wise to monitor the $\mathrm{pH}$ of this water throughout the experiment, while analysis of total alkalinity (TA) and dissolved inorganic carbon (DIC) would provide a better idea about the aqueous carbonate system, computed using common software for aqueous geochemistry. Furthermore, condensation was noted on the inside of the lids of the Petri dishes, mostly on the samples cultivated at cave temperature $\left(10^{\circ} \mathrm{C}\right)$, which then may have fallen onto the tablets. This could have been lessened by first cooling the Petri dishes and the water, separately, to the temperature at which the experiment will be carried out, before construction of the experimental set-up. Here, we had used glass Petri dishes due to the availability of a suitable container, high enough to accommodate the tablets. The use of a plastic container with a higher headspace and a smaller footprint would require less water while increasing the comparable volume of air, likely resolving this condensation problem.
Our results indicate problems resolving microbes that derived from the cave and those that were due to contamination. Although this problem should be resolved already by using an improved sterilization techniques, such as autoclaving, the identification of microorganisms before and after inoculation (if enough material is available) could show if the microbes came from the cave or from contamination. Moreover, here, we interpret microbes present on the cave water controls as possibly deriving from incomplete sterilization of the cave water via filtering. An additional UV treatment of the cave waters would ensure complete sterilization. However, dead cells would still be present and, thus, visible on the SEM images, which may act as a nucleus for mineral deposition. Another approach could be to incubate the filtered cave waters on agar plates to assess if any microbes grew, to confirm if microbes smaller than $0.2 \mu \mathrm{m}$ avoided the sterilization by filtering.

On completion of the experiment, we found that air-drying of the samples caused circular evaporation features. The formation of these may already be reduced by using the methods, outlined above, for the reduction of condensation. However, an investigation into alternative drying techniques, such as critical point drying, is required to see if such techniques would affect the rock surface. A better drying technique should resolve the problem of the evaporation circles and may also improve the preservation of microbial morphology.

Future study should include prolonged cultivation to elucidate if longer incubation periods can be an important factor to direct biofilm formation in oligotrophic conditions. These longer incubation periods may increase colony size and coverage of the tablet surface, thus, providing more opportunity to gain evidence of microbial-mediation of carbonate dissolution and precipitation. After the initial visualization of the tablets by SEM, a second step to future experiments could involve stripping of the EPS, possibly carried out manually without altering the tablet surface, which may expose the concealed dissolution features thought to be masked by thick EPS (see Discussion and Fig. 5D). Further work, could use spectroscopic analysis of the crystals present to distinguish between $\mathrm{CaCO}_{3}$ polymorphs. Additionally, an identification of the microbial species present should be carried out. Isolation of the most abundant cave microbial species and experimentation under varying environmental conditions may allow further insight into whether the processes of carbonate dissolution or precipitation are species dependent, or whether these processes are (to a greater extent) dependent on the environmental conditions (e.g., pH, temperature, nutrient availability). Furthermore, investigation into links between species and the morphology of precipitated crystals and/or the intensity or style of dissolution would provide further information that may be useful for understanding the formation of cave biokarst features and their implications for the preservation of prehistoric cave art and past climate proxy signals in speleothems. 
Carbonate tablets were inoculated with microbes collected from Postojna Cave, Slovenia, and incubated in dark, oligotrophic conditions for 2 and 14 weeks at $10^{\circ} \mathrm{C}$ (cave temperature) and $20^{\circ} \mathrm{C}$. The tablets were then observed with an SEM to identify calcitemicrobe interactions to give insights into how microbes interact with carbonate rock under ambient conditions with limited nutrients. However, our study was plagued by a number of problems, most notably an incomplete sterilization of the tablet rock. Our evidence of incomplete sterilization of a rock surface when wiped with 96\% ethanol followed by flushing with $96 \%$ followed by $70 \%$ ethanol should be taken into consideration for future studies when a complete absence of microbial life is needed on stony, inhomogeneous, or micro-fractured surfaces. We have identified many limitations of our experimental method and how these may have caused bias in the interpretation of results, and importantly, we have provided suggestions to remediate these issues for future experiments. Nonetheless, our study showed evidence of microbially-mediated carbonate dissolution and precipitation associated with visible microbial colonies and EPS and, thus, provides an insight into the role that microbes play in cave biokarst, with implications for the preservation of prehistoric cave art and past climate proxy signals in speleothems.

\section{ACKNOWLEDGEMENTS}

The authors acknowledge the projects J19185: "Terrestrial carbonates: mineral products of geobiological processes in the critical zone" and L69397: "Methodology for monitoring the sustainable use of karst show caves with automatic measurements - role model - Postojna cave" that were financially supported by the Slovenian Research Agency. Thanks to Mineral d.o.o, Lesno Brdo Quarry, for providing the limestone samples. We thank Adrijan Košir (PIIR, ZRC SAZU) for productive discussion and technical help during the preparation of the tablets and the work at the SEM. Kata Cvetko Baric and Katarina Kadivec assisted in the preparation of the tablets. We thank Franci Gabrovšek (IZRK, ZRC SAZU) for enthusiastically introducing us to the question of how the intriguing dissolution cups are forming in Postojna Cave and Lovel Kukuljan (IZRK, ZRC SAZU) for participating in the cave monitoring campaign and analyzes of water geochemistry. Mladen Franko (University of Nova Gorica) provided instrumentation for analyzes of major ions in cave waters. We thank Editor Hazel Barton and anonymous reviewers for their excellent suggestions that substantially improved the manuscript.

Authorship statement: JM, VEJ, and AMP conceived and designed the experiment. VEJ and AMP carried out the fieldwork. SS, VEJ, and AMP carried out the laboratory work. AMP and VEJ analyzed the samples. VEJ carried out the interpretations and wrote the manuscript with input from all authors.
Barton, H.A., Northup, D.E., 2007. Geomicrobiology in cave environments: past, current and future perspectives. Journal of Cave and Karst Studies, 69, 163-178.

Bennett, P.C., Summers Engel, A., Roberts, J.A., 2006. Counting and imaging bacteria on mineral surfaces: In Methods of investigating microbial-mineral interactions, CMS Workshop Lectures, Vol. 14, Maurice, P.A., Warren, L.A. (Eds.), The Clay Mineral Society, Chantilly, VA, p. 37-78.

Blyth, A.J., Hartland, A., Baker, A., 2016. Organic proxies in speleothems - New developments, advantages and limitations. Quaternary Science Reviews, 149, 1-17. https://doi.org/10.1016/j.quascirev.2016.07.001

Bontognali, T.R., D'Angeli, I.M., Tisato, N., Vasconcelos, C., Bernasconi, S.M., Gonzales, E.R., De Waele, J., 2016. Mushroom speleothems: stromatolites that formed in the absence of phototrophs. Frontiers in Earth Science, 4, 49.

https://doi.org/10.3389/feart. 2016.00049

Braissant, O., Bindschedler, S., Daniels, A.U., Verrecchia, E.P., Cailleau, G., 2012. Microbiological activities in moonmilk monitored using isothermal microcalorimetry (Cave of Vers Chez le Brandt, Neuchatel, Switzerland). Journal of Cave and Karst Studies, 74, 116-126.

https://doi.org/10.4311/2011jcks0213

Bullen, H.A., Oehrle, S.A., Bennett, A.F., Taylor, N.M., Barton, H.A., 2008. Use of attenuated total reflectance Fourier Transform Infrared Spectroscopy to identify microbial metabolic products on carbonate mineral surfaces. Applied and Environmental Microbiology, 74, 4553-4559.

https://doi.org/10.1128/AEM.02936-07

Cañaveras, J., Cuezva, S., Sánchez-Moral, S., Lario, J., Laiz, L., González, J., Saiz-Jiménez, C., 2006. On the origin of fiber calcite crystals in moonmilk deposits. Naturwissenschaften, 93, 27-32.

https://doi.org/10.1007/s00114-005-0052-3

Cuezva, S., Sanchez-Moral, S., Saiz-Jimenez, C., Cañaveras, J.C., 2009. Microbial communities and associated mineral fabrics in Altamira Cave, Spain. International Journal of Speleology, 38(1), 83-92. https://doi.org/10.5038/1827-806X.38.1.9

Cuezva, S., Fernandez-Cortes, A., Porca, E., Pašić, L., Jurado, V., Hernandez-Marine, M., Serrano-Ortiz, P., Hermosin, B., Cañaveras, J.C., Sanchez-Moral, S., Saiz-Jimenez, C., 2012. The biogeochemical role of Actinobacteria in Altamira Cave, Spain. FEMS Microbiology Ecology, 81, 281-290. https://doi.org/10.1111/j.1574-6941.2012.01391.x

Cunningham, K.I., Northup, D.E., Pollastro, R.M., Wright, W.G., LaRock, E.J., 1995. Bacteria, fungi and biokarst in Lechuguilla Cave, Carlsbad Caverns National Park, New Mexico. Environmental Geology, 25, 2-8. https://doi.org/10.1007/BF01061824

Curry, M.D., Boston, P.J., Spilde, M.N., Baichtal, J.F., Campbell, A.R., 2009. Cottonballs, a unique subaqeous moonmilk, and abundant subaerial moonmilk in Cataract Cave, Tongass National Forest, Alaska. International Journal of Speleology, 38(2), 111-128. https://doi.org/10.5038/1827-806X.38.2.3

Davis, K.J., Nealson, K.H., Lüttge, A., 2007. Calcite and dolomite dissolution rates in the context of microbemineral surface interactions. Geobiology, 5, 191-205. https://doi.org/10.1111/j.1472-4669.2007.00112.x 
De Leo, F., Iero, A., Zammit, G., Urzì, C., 2012. Chemoorganotrophic bacteria isolated from biodeteriorated surfaces in cave and catacombs. International Journal of Speleology, 41(2), 125-136.

https://doi.org/10.5038/1827-806X.41.2.1

De Muynck, W., De Belie, N., Verstraete, W., 2010. Microbial carbonate precipitation in construction materials: A review. Ecological Engineering, 36, 118136. https://doi.org/10.1016/j.ecoleng.2009.02.006

Dupraz, C, Reid, R.P., Braissant, O., Decho, A.W., Norman, R.S., Visscher, P.T., 2009. Processes of carbonate precipitation in modern microbial mats. Earth-Science Reviews, 96, 141-162.

https://doi.org/10.1016/j.earscirev.2008.10.005

Engel, A.S., Stern, L.A., Bennet, P.C., 2004. Microbial contributions to cave formation: new insights into sulfuric acid speleogenesis. Geology, 32, 369-372. https://doi.org/10.1130/G20288.1

Fratesi, S.E., Lynch, F.L., Kirkland, B.L., Brown, L.R., 2004. Effects of SEM preparation techniques on the appearance of bacteria and biofilms in the Carter Sandstone. Journal of Sedimentary Research, 74, 858867. https://doi.org/10.1306/042604740858

Hahn, M.W., 2004. Broad diversity of viable bacteria in 'sterile' $(0.2 \mu \mathrm{m})$ filtered water. Research in Microbiology, 155, 688-691.

https://doi.org/10.1016/j.resmic.2004.05.003

Hartland, A., Fairchild, I.J., Lead, J.R., Zhang, H., Baalousha, M., 2011. Size, speciation and lability of NOM-metal complexes in hyperalkaline cave dripwater. Geochimica et Cosmochimica Acta, 75, 7533-7551.

https:/doi.org/10.1016/j.gca.2011.09.030

Jacobson, A.D., Wu, L., 2009. Microbial dissolution of calcite at $\mathrm{T}=28^{\circ} \mathrm{C}$ and ambient $\mathrm{pCO}_{2}$. Geochimica et Cosmochimica Acta, 73, 2314-2331.

https://doi.org/10.1016/j.gca.2009.01.020

Johnston, V.E., Kukuljan, L., Gabrovšek, F., MartínPérez, A., Košir, A., 2018. Curious cup-shaped dissolutional features in a dead-end passage of Postojna Cave, Slovenia. In: Prelovšek, M. (Ed.), Proceedings of the 26th International Karstological School "Show caves and science". ZRC Publishing, Ljubljana, 72 p.

Johnston, V.E., Martín-Pérez, A., Košir, A., Gabrovšek, F., Kukuljan, L., 2019. Estimation of calcite dissolution and precipitation rates in a $\mathrm{CO}_{2}$-rich cave chamber using limestone tablets and SEM imaging techniques. 16th Bathurst Meeting, Book of abstracts, 64 p.

Jones, B., 2010. Microbes in caves: agents of calcite corrosion and precipitation. In: Pedley, H.M., Rogerson, M. (Eds.), Tufas and speleothems: unravelling the microbial and physical controls. Geological Society, London, Special Publications, 336, p. 7-30.

https://doi.org/10.1144/SP336.2

Jones, B., Pemberton, S.G., 1987. Experimental formation of spiky calcite through organically mediated dissolution. Journal of Sedimentary Petrology, 57, 687-694.

Kip, N., van Veen, J.A., 2015. The dual role of microbes in corrosion. The International Society for Microbial Ecology Journal, 9, 542-551.

https://doi.org/10.1038/ismej.2014.169

Konhauser, K., 2016. Geomicrobial interactions with silicon. In: Ehrlich, H.L., Newman, D.K., Kappler, A. (Eds.), Ehrlich's Geomicrobiology (6th Ed). CRC Press, Boca Raton, p. 237-256.

Krajnc, B., Ferlan, M., Ogrinc, N., 2017. Soil $\mathrm{CO}_{2}$ sources above a subterranean cave-Pisani rov (Postojna Cave, Slovenia). Journal of Soil Sediments, 17, 1883-1892. https:/doi.org/10.1007/s11368-016-1543-x
Krause, S., Aloisi, G., Engel, A., Liebetrau, V., Treude, T., 2014. Enhanced calcite dissolution in the presence of the aerobic methanotroph methylosinus trichosporium. Geomicrobiology Journal, 31, 325-337.

https://doi.org/10.1080/01490451.2013.834007

Kukuljan, L., Johnston, V.E., Gabrovšek, F., 2018. Insights into spatial and seasonal $\mathrm{CO}_{2}$ variability in a dead-end passage of Postojna Cave, Slovenia. In: Prelovšek, M. (Ed.), Proceedings of the 26th International Karstological School "Show caves and science”, ZRC publishing, Ljubljana, p. 74-75.

Kukuljan, L., Gabrovšek, F., Covington, M., Johnston, V.E., 2021. $\mathrm{CO}_{2}$ dynamics and heterogeneity in a cave atmosphere: Role of ventilation patterns and airflow pathways. Preprint at doi:

https://doi.org/10.13140/RG.2.2.17204.17284

Lavoie, K.H., Northup, D.E., Barton H.A., 2010. Microbemineral interactions. In: Sudhir, K.J., Khan, A.A., Rai, M.A. (Eds.), Cave microbiology. Science Publishers, p. 1-45.

Li, Q., Zhang, B., Ge, Q., Yang, X., 2018. Calcium carbonate precipitation induced by calcifying bacteria in culture experiments: influence of the medium on morphology and mineralogy. International Biodeterioration and Biodegradation, 134, 83-92. https://doi.org/10.1016/j.ibiod.2018.08.006

Li, W., Yu, L-J., Wu, Y., Jia, L-P., Yuan, D-X., 2006. Enhancement of $\mathrm{Ca}^{2+}$ release from limestone by microbial extracellular carbonic anhydrase. Bioresource Technology, 98, 950-953. https://doi.org/10.1016/j.biortech.2006.03.021

Li, X., Wong, C., Ng, T., Zhang, C., Leung, K.C., Jin, L., 2016. The spherical nanoparticle-encapsulated chlorhexidine enhances anti-biofilm efficiency through an effective releasing mode and close microbial interactions. International Journal of Nanomedicine, 11, 2471-2480. https://doi.org/10.2147/IJN.S105681

Lian, B., Chen, Y., Zhu, L., Yang, R., 2008. Effect of microbial weathering on carbonate rocks. Earth Science Frontiers, 15, 90-99.

https://doi.org/10.1016/S1872-5791(09)60009-9

Lundberg, J., Brewer-Carías, C., McFarlane, D.A., 2018. On biospeleothems from a Venezuelan tepui cave: U-Th dating, growth rates, and morphology. International Journal of Speleology, 47(3), 361-378. https://doi.org/10.5038/1827-806X.47.3.2212

Lüttge, A., Conrad, P.G., 2004. Direct observation of microbial inhibition of calcite dissolution. Applied and Environmental Microbiology, 70, 1627-1632. https://doi.org/10.1128/AEM.70.3.1627-1632.2004

Maciejewska, M., Adam, D., Loïc, M., Naômé, A., Całusińska, M., Delfosse, P., Carnol, M., Barton, H.A., Hayetten, M-P., Smargiasso, N., De Pauw, E., Hanikenne, M., Baurain, D., Rigali, S., 2016. A phenotypic and genotypic analysis of the antimicrobial potential of cultivable Streptomyces isolated from cave moonmilk deposits. Frontiers in Microbiology, 7, 1455. https://doi.org/10.3389/fmicb.2016.01455

Männik, J., Driessen, R., Galajda, P., Keymer, J.E., Dekker, C., 2009. Bacterial growth and motility in sub-micron constrictions. Proceedings of the National Academy of Sciences of the United States of America, 106, 14861-14866.

https://doi.org/10.1073/pnas.0907542106

Melim, L.A., Shinglman, K.M., Boston, P.J., Northup, D.E., Spilde, M.N., Queen, J.M., 2001. Evidence for microbial involvement in pool finger precipitation, Hidden Cave, New Mexico. Geomicrobiology Journal, 18, 311-329.

https://doi.org/10.1080/01490450152467813 
Miller, A.Z., Garcia-Sanchez, A.M., Martin-Sanchez, P.M., Pereira, M.F.C., Spangenberg, J.E., Jurado, V., Dionisio, A., Afonso, M.J., Chaminé, H.I., Hermosin, B., Saiz-Jimenez, C., 2017. Origin of abundant moonmilk deposits in a subsurface granitic environment. Sedimentology, 65, 1482-1503. https://doi.org/10.1111/sed.12431

Morse, J.W., MacKenzie, F.T., 1990. Geochemisty of sedimentary carbonates. Developments in Sedimentology, 48, Amsterdam, Elsevier, 707 p.

Mulec, J., Oarga-Mulec, A., 2016. ATPluminescence assay as a bioburden estimator of biomass accumulation in caves. International Journal of Speleology, 45(3), 207218. https://doi.org/10.5038/1827-806X.45.3.1975

Oarga-Mulec, A, Holko, L., Kopitar, A.N., Mulec, J., 2017. Study of water cycle in karst with chemical and microbiological parameters. In: Gostinčar, P. (Ed.). Proceedings of the 25th International Karstological School "Milestones and challenges in karstology", Postojna, ZRC Publishing, Ljubljana, p. 43-44.

Parkhurst, D.L., Appelo, C.A.J., 2013. Description of input and examples for PHREEQC version 3-A computer program for speciation, batch-reaction, one-dimensional transport, and inverse geochemical calculations. In: U.S. Geological Survey Techniques and Methods, Book 6, Chapter A43, 497 p.

https://pubs.usgs.gov/tm/06/a43/

Perry, D.T., Duckworth, O.W., McNamara, C.J., Martin, S.T., Mitchell, R., 2004. Effects of the biologically produced polymer alginic acid on macroscopic and microscopic calcite dissolution rates. Environmental Science \& Technology, 38, 3040-3046.

https://doi.org/10.1021/es035299a

Portillo, M.C., Gonzalez, J.M., 2010. Differential effects of distinct bacterial biofilms in a cave environment. Current Microbiology, 60, 435-438. https://doi.org/10.1007/s00284-009-9561-1

Pouget, E.M., Bomans, P.H.H., Goos, J.A.C.M., Frederik, P.M., de With, G., Sommerdijk, N.A.J.M., 2009. The initial stages of template-controlled $\mathrm{CaCO}_{3}$ formation revealed by Cryo-TEM. Science, 323, 1455-1458. https://doi.org/10.1126/science.1169434

Ridgwell, A., Zeebe, R., 2005. The role of the global carbonate cycle in the regulation and evolution of the Earth system. Earth and Planetary Science Letters, 234, 299-315.

https://doi.org/10.1016/j.eps1.2005.03.006

Rusznyák, A., Akob, D. M., Nietzsche, S., Eusterhues, K., Totsche, K. U., Neu, T. R., Frosch, T., Popp, J., Keiner, R., Geletneky, J., Katzschmann, L., Schulze, E., Küsel, $\mathrm{K}, 2012$. Calcite biomineralization by bacterial isolates from the recently discovered pristine karstic Herrenberg Cave. Applied and Environmental Microbiology, 78, 1157-1167. https://doi.org/10.1128/AEM.06568-11

Sauro, F., Cappelletti, M., Ghezzi, D., Columbu, A., Hong, P-Y., Zowawi, H.M., Carbone, C., Piccini, L., Vergara, F., Zannoni, D., DeWaele, J., 2018. Microbial diversity and biosignatures of amorphous silica deposits in orthoquartzite caves. Scientific Reports, 8, 17569. https://doi.org/10.1038/s41598-018-35532-y

Sebela, S., 2010. Accesses from the surface to the Postojna Cave system. Annales, Series Historia Naturalis, 20, 55-64.

Shabarova, T., Villiger, J., Morenkov, O., Niggemann, J., Dittmar, T., Pernthaler, J., 2014. Bacterial community structure and dissolved organic matter in repeatedly flooded subsurface karst water pools. FEMS Microbiology Ecology, 89, 111-126.

https://doi.org/10.1111/1574-6941.12339

Shen, Y., Chapelle, F.H., Strom, E.W., Benner, R., 2015. Origins and bioavailability of dissolved organic matter in groundwater. Biogeochemistry, 122, 61-78. https://doi.org/10.1007/s10533-014-0029-4

Simon, K.S., Pipan, T., Culver, D.C., 2007. A conceptual model of the flow and distribution of organic carbon in caves. Journal of Cave and Karst Studies, 69, 279-284.

Thomas, P., 2012. Long-term survival of Bacillus spores in alcohol and identification of $90 \%$ ethanol as relatively more spori/bactericidal. Current Microbiology, 64, 130-139. https://doi.org/10.1007/s00284-011-0040-0

Tünde Enyedi, N., Makk, J., Kótai, L., Berényi, B., Klébert, S., Sebestyén, Z., Molnár, Z., Borsodi, A.K., Leél-Őssy, S., Demény, A., Németh, P., 2020. Cave bacteria-induced amorphous calcium carbonate formation. Scientific Reports, 10, 8696. https://doi.org/10.1038/s41598-020-65667-w

Vainshtein, M.B., Kudryashova, E.B., 2000. Nannobacteria. Microbiology, 69, 129-138. https://doi.org/10.1007/BF02756186

Warscheid, Th., Braams, J., 2000. Biodeterioration of stone: a review. International Biodeterioration \& Biodegradation, 46, 343-368.

https://doi.org/10.1016/S0964-8305(00)00109-8

Zhuang, D., Yan, H., Tucker, M.E., Zhao, H., Han, Z., Zhao, Y., Sun, B., Li, D., Pan, J., Zhao, Y., Meng, R., Shan, G., Zhang, X., Tang, R., 2018. Calcite precipitation induced by Bacillus cereus MRR2 cultured at different $\mathrm{Ca}^{2+}$ concentrations: Further insights into biotic and abiotic calcite. Chemical Geology, 500, 64-87. https://doi.org/10.1016/j.chemgeo.2018.09.018 